\title{
Unraveling the MNE wage premium
}

\author{
Khadija van der Straaten ${ }^{1,2}$, \\ Niccolò Pisani ${ }^{1}$ and Ans Kolk ${ }^{1}$ \\ ${ }^{1}$ Amsterdam Business School, University of \\ Amsterdam, Amsterdam, The Netherlands; \\ ${ }^{2}$ Rotterdam Business School, Rotterdam University \\ of Applied Sciences, Rotterdam, The Netherlands \\ Correspondence: \\ A Kolk, Amsterdam Business School, \\ University of Amsterdam, Amsterdam, The \\ Netherlands \\ e-mail: akolk@uva.nl
}

\begin{abstract}
Whereas IB has extensively studied MNEs' generic (positive) impact on host economies, but rarely on employee wages, economics research has only shown an overall MNE wage premium. We 'unravel' this premium, considering multiple levels of analysis and accounting for host-country contextual contingencies, to unveil MNEs different (positive or negative) distributional effects. Using unique micro-level data from over 40,000 employees in 13 countries, we examine MNEs' distributional effects for employees' gender, experience, and immigrant status; the influence of host-country property rights protection and labor regulation; and interplays with region and industry effects. MNEs' distributional effects show marked differences that largely depend on the host-country context, and that are positive for experienced and foreignborn employees in developed countries but negative for females working in developing countries. Whereas in developed countries the gender wage gap is smaller in MNEs than in domestic firms as hypothesized, we find evidence of a larger wage gap in developing countries. The analysis also reveals that the higher host-countries' level of property rights protection, the lower the MNE wage premium. Our study points at the need to reassess statements about the generic positive impact of MNEs in host countries, particularly in developing countries, and discusses (further) research implications.
\end{abstract}

Journal of International Business Studies (2020) 51, I355-1390.

https://doi.org/10.1057/s4 I 267-019-00285-x

Keywords: multinational corporations (MNCs) and enterprises (MNEs); domestic firms; employees; wage premia; multilevel analysis; gender equality

The online version of this article is available Open Access

\section{INTRODUCTION}

The implications of multinational enterprises' (MNEs) presence in a given host country has been a central topic of scholarly enquiry in the international business (IB) literature. Most prominently, an extensive body of IB research has investigated MNEs' productivity spillovers to local actors since Caves' first publication on the topic in 1974 (e.g., Giroud, 2007; Meyer \& Sinani, 2009; Narula, 2014; Zanfei, 2012). This work has tended to emphasize the potential, often unintended, positive effects of MNEs on host-country economic development through these spillovers (Oetzel \& Doh, 2009). Several other IB studies have focused on MNEs' social role and responsibilities in host countries, highlighting the dilemmas faced when operating abroad, especially in emerging economies
Received: 16 June 2018

Revised: 11 October 2019

Accepted: 22 October 2019

Online publication date: 10 December 2019 
(for recent overviews see Kolk, 2016; Pisani, Kourula, Kolk, \& Meijer, 2017). While, overall, this stream of research has contributed to enhancing our insight into MNEs' influence on host countries and local firms, several themes have been understudied. Specifically, the IB literature has thus far only offered a very limited understanding of how MNEs affect local wages, which is a striking omission given the connections that are increasingly made between firms' internationalization and growing wage differentials (Haskell, Lawrence, Leamer, \& Slaughter, 2012; Kobrin, 2017), and the fact that MNEs can have a substantive 'standardsetting' influence through their wage payments (Bapuji, Husted, Lu, \& Mir, 2018) - positively or negatively when seen from an inequality perspective (Giuliani, 2019).

Although a few qualitative publications have shed some light on MNEs' role concerning employees' pay and work practices in the host countries in which they operate (e.g., Egels-Zandén, 2014; Tatoglu, Glaister, \& Demirbag, 2016), we note that thus far the IB literature has paid scant attention to this topic. In the broader realm of wages, salaries, and compensation, ${ }^{1}$ there are studies on the link between culture and pay practices (e.g., Schuler \& Rogovsky, 1998; Van de Vliert, 2003), the compensation of international executives and expats (e.g., Hon \& Lu, 2015; Southam \& Sapp, 2010; Van Essen, Heugens, Otten, \& Van Oosterhout, 2012) and, more generally, on the convergence and divergence of human resource management practices across market economies (Farndale, Brewster, Ligthart, \& Poutsma, 2017). However, only very few focus on MNEs' wage payments to employees in their subsidiaries, such as Girma, Görg, and Kersting (2019) who examined how the proportion of foreign direct investment (FDI) in an industry cluster affects the wages paid by MNEs and domestic firms in China; and Clougherty, Gugler, Sørgard, and Szücs (2014) who studied how firms' international activity affects wages, though restricted to the effect of cross-border mergers on wages in the US. Very recently, Doh (2019) reiterated the need for more research on the role of MNEs in contributing to inequality, with specific attention for wage inequality (cf. Narula, 2019).

In this paper, we aim to fill this gap in the existing body of knowledge and start from empirical findings of publications in international economics (e.g., Aitken, Harrison, \& Lipsey, 1996; Hijzen, Martins, Schank, \& Upward, 2013; Javorcik, 2014) that have consistently shown the existence of what has been called an MNE (or foreign ownership) wage premium. The dominant explanation of such premium, relying on the IB literature, is that MNEs derive a productivity advantage (over domestic firms) from firm-specific knowledge (Caves, 1996; Dunning, 1988; Rugman \& Verbeke, 2001), and that this advantage may be eroded when knowledge spills over as a result of employees leaving the firm (Ben Hamida, 2013). To prevent these spillovers, MNEs therefore tend to pay a wage premium to retain their employees in host countries (Fosfuri, Motta, \& Rønde, 2001; Glass \& Saggi, 1999, 2002; Globerman, Ries, \& Vertinsky, 1994). However, while these studies have contributed to identifying the very existence of the MNE wage premium, they have overlooked (a) the distributional effects associated with MNEs' presence in the host-country context, (b) how institutional contingencies influence the MNE wage premium, and (c) the interplay between these effects. In other words, although extant research has shown that it 'pays' to work for a multinational in generic terms, we still do not know for whom and how more exactly, also in relation to types of countries and industries.

We zoom in on these aspects through a more indepth investigation, focusing on foreign-owned subsidiaries of MNEs versus purely domestic firms (which neither have any activities in foreign countries nor any foreign ownership). This enables us to isolate the MNE wage effect to then unravel it. Our paper unveils the distributional effects associated with the MNE wage premium in relation to three key employees' characteristics: their gender, experience, and immigrant status. Specifically, building on insights from different bodies of literature, and as explained in more detail in the theory and hypotheses section, we expect (1) the gender wage gap to be smaller in MNEs (than domestic firms), (2) the experience wage premium to be larger in MNEs; and (3) the immigrant wage gap to be smaller in MNEs. We also propose two key contingencies associated with the host-country institutional environment-property rights protection and labor freedom - and expect a smaller MNE wage premium when property rights are better protected and labor regulations stricter.

We test the hypothesized relationships with unique micro-level data from over 40,000 employees from 13 countries and 32 different industries. Our results show that the gender wage gap is smaller in MNEs than domestic firms, but only in developed countries. Contrary to our expectations, 
the gender wage gap turns out to be even larger in MNEs than domestic firms in developing countries. Our findings empirically validate that the experience wage premium is larger in MNEs; they also confirm that the immigrant wage gap is smaller in MNEs, but the difference vis-à-vis domestic firms is significant only for developed countries. In relation to the effect of host-country institutions, we find evidence that the higher the level of property rights protection, the lower the MNE wage premium. We also perform a number of post hoc analyses that reveal the interplay of MNEs' distributional effects with host-country institutions and the presence of specific region and industry effects.

Our work contributes to the IB field in several ways. First, by 'unraveling' the MNE wage premium and clarifying specific MNE distributional effects considering employees' gender, experience, and immigrant status - our work generates new insights into MNEs' influence on host countries. We show that these effects are not always positive, most notably that MNEs contribute to widening the gender wage gap in developing countries. In this way, our study adds important empirical evidence in support of earlier observations that, while IB research has tended to overly focus on the positive effects of FDI on development, reality seems much more nuanced as MNE activity is not a conditio sine qua non for development, especially in those regions where people are most in need (Dunning, 1994; Lall, 1980; Lall \& Narula, 2004; Narula \& Driffield, 2012; Narula \& Dunning, 2010). We also uncover the influence of host-country institutions on the different components of the MNE wage premium. Linking our work to earlier insights from the IB literature, we illustrate the important role of property rights protection in moderating the effect of MNEs on employee wages. Furthermore, methodologically, ours is - to our knowledge the first empirical study on wage differentials that uses a multilevel mixed effects method that allows us to account in our estimation for different sources of heterogeneity related to the MNE wage premium and thus properly model the interaction between MNEs' distributional effects and host-country institutions.

\section{THEORY AND HYPOTHESES}

\section{The Influence of MNEs on Host Countries}

An extensive body of IB research has focused on the influence of MNEs' presence in a given host country. This work has investigated a variety of relevant topics, such as the positive impact associated with MNEs' active role in filling institutional voids (Kolk \& Lenfant, 2015; Parmigiani \& RiveraSantos, 2015) and the development of better local institutions (Cantwell, Dunning, \& Lundan, 2010; Kwok \& Tadesse, 2006; Regnér \& Edman, 2014). One of the most researched effects in this body of work involves the potential productivity advances of local firms benefiting from knowledge spillovers from MNEs' subsidiaries based in their geographical proximity (e.g., Altomonte \& Pennings, 2009; Buckley, Clegg, \& Wang, 2007; Giroud, 2007; Ha \& Giroud, 2015; Meyer \& Sinani, 2009). This positive effect arises because MNEs possess firmspecific advantages (FSAs) - stand-alone resources such as technology and managerial processes, and higher-order FSAs such as the capacity to create, recombine, and (un)bundle these resources - that local firms in the host country do not have (Da Silva Lopes, Casson, \& Jones, 2019; Narula, Asmussen, Chi, \& Kundu, 2019; Narula \& Verbeke, 2015; Strange \& Humphrey, 2019).

MNEs can transfer FSAs to local firms within their supply chains through vertical linkages. Prior studies have shown that upstream backward linkages with local suppliers facilitate the transfer of knowledge and skills (Giroud, 2007; Jindra, Giroud, \& Scott-Kennel, 2009), while downstream forward linkages with buyers and distributors lead to the transfer of knowledge embodied in products, processes, and technologies (Driffield, Munday, \& Roberts, 2002; Miozzo \& Grimshaw, 2008). Horizontal spillovers in favor of domestic firms - thus labeled as negative for the focal MNE - can occur as well, for instance through imitation by local competitors (Ben Hamida \& Gugler, 2009), or when employees switch jobs and take their firm-specific knowledge out of the MNEs' subsidiary (Ben Hamida, 2013). IB scholars have also unveiled the key role of contingencies in the creation of the above-mentioned spillovers between MNEs and local firms, for example with respect to the level of MNEs' subsidiary autonomy (Ha \& Giroud, 2015; Jindra et al., 2009), domestic firms' absorptive capacity (Ben Hamida, 2013; Blalock \& Simon, 2009; Zanfei, 2012), and the role of MNEs' country of origin (Buckley et al., 2007), and host-country and industry characteristics (Giuliani \& Macchi, 2014).

Over the years, often as part of their corporate social responsibility (CSR) policies, MNEs have started to communicate more actively about the 
various types of impact they have when operating abroad, including not only social and environmental but also economic dimensions such as jobs created and figures on total taxes and (cash) value added for different stakeholder groups (e.g., Fortanier \& Kolk, 2007). Although this information is usually self-reported, it has helped to raise attention to the broader implications of MNEs' activities in developing countries, considering the economy (e.g., the special issue edited by Ghauri \& Yamin, 2009), as well as the environment, stakeholders, and ethics (cf. Giuliani \& Macchi, 2014; Meyer, 2004). And while IB research has maintained a strong focus on the social role and responsibilities that MNEs have when operating abroad -for instance investigating the relationship between MNEs and stakeholders, including NGOs, in host countries (Kourula \& Laasonen, 2010; Oetzel \& Doh, 2009; Pisani et al., 2017) - IB scholarly efforts have increasingly focused on furthering our understanding of the effect of MNEs' presence in host economies including a broader set of dimensions in their analyses.

It is important to note that, whereas IB research has tended to overwhelmingly focus on the positive effects of MNEs' presence in host countries (such as the ones discussed in the preceding paragraphs), scholars such as Dunning $(1958,1981,1994)$ have emphasized that not all outcomes from the participation of MNEs in the host economy may be positive. For example, when MNEs only locate lowvalue adding activities in the host country, they thereby restrict the potential for positive spillovers. Such negative effects can even turn into an overall negative net effect associated with MNEs' presence, which materializes for instance when the benefits from MNE spillovers (and other factors contributing to host-country development) are smaller than the negative effects, or when the investment in local capabilities necessary to absorb and internalize MNE spillovers is larger than the payoff by itself (Narula \& Driffield, 2012; Narula \& Dunning, 2010; Zanfei, 2012). Moreover, even similar acts by the same MNE could generate very different outcomes in different host countries, as effects also depend on several specificities of the local context, which include host-country capabilities and associated absorptive capacity, institutions and industrial structures (Dunning, 1994; Lall, 1980; Lall \& Narula, 2004; Meyer \& Peng, 2005).

This body of work has thus suggested - different from predominant IB attention on the positive effects of FDI to development - that the whole range of possible impacts, including negative ones, need to be taken into account and that MNE activity is not a conditio sine qua non for development as such. Yet, we still have a limited understanding, both conceptually and empirically, of the nature and magnitude of the negative effects of MNE presence for host countries (Narula \& Dunning, 2010). While partly due to a perhaps somewhat overly optimistic view on the influence of MNEs in host countries, there has also been a relative paucity of data and concomitant difficulties to examine such effects in more detail (Giuliani \& Macchi, 2014; Narula \& Driffield, 2012). Recent publications in IB journals have, however, pointed at the need for more research also on the possible negative effects, such as the role of resource-seeking MNEs in depleting natural resources (Narula, 2018), the impact of FDI in land in agriculture on hostcountry food security (Santangelo, 2018), and more generally, to include more dimensions of sustainable development, including poverty, human and labor rights, and working conditions (Kolk, 2016).

However, besides a few studies that have shed light on the existence of differences in work practices across countries (Ollo-Lopez, Bayo-Moriones, \& Larraza-Kintana, 2011) and more specifically on MNEs' effect on employees' working conditions in their international supply chains, particularly in the case of developed-country MNEs (e.g., Egels-Zandén, 2014), we note that thus far the IB literature has paid scant attention to the distributional effects of MNEs' presence in host countries, especially in relation to the wages paid by MNEs to their own employees. We find this particularly striking because understanding MNEs' influence on wages in the host countries in which they operate is highly relevant for the field, especially when it comes to contributing to scholarly debates about the potentially negative effects of MNEs' activities just mentioned. Several recent publications have also emphasized the link between globalization and wage differences (Bourguignon, 2015; Chen, Ge, \& Lai, 2011; Haskell et al., 2012; Kobrin, 2017; Lee \& Wie, 2015; Milanovic, 2016).

As indicated in the Introduction, there is hardly any IB research on wages and the more generic management literature has merely examined gender gaps in wages within organizations (e.g., Abraham, 2017; Briscoe \& Joshi, 2017; Cardador, 2017). None of these studies has empirically investigated MNEs' distributional effects in host countries and their interplay with host-country institutions, a gap that we aim to fill with this study. 


\section{The MNE Wage Premium}

Particularly the international economics literature has investigated whether MNEs pay higher wages than domestic firms. The empirical evidence accumulated largely supports this claim (e.g., Almeida, 2007; Chen et al., 2011; Girma et al., 2019; Heyman, Sjöholm, \& Tingvall, 2007; Hijzen et al., 2013). Specifically, the MNE wage premium found in these studies, which focus mostly on manufacturing industries, ranges between 2 and 20\%. The majority of these earlier works have relied on efficiency arguments to explain the MNE wage premium, especially linked to MNEs' need to retain employees in order to prevent spillovers. Through training and experience, MNEs' local employees become familiar with firm-specific technology and management practices (Martin \& Salomon, 2003), and this knowledge and skills are at risk of spilling over when employees switch employers or start their own companies in the host country (Ben Hamida, 2013; Blomström \& Kokko, 2002; Meyer, 2004; Sinani \& Meyer, 2004). In order to prevent these spillovers, MNEs, deriving a larger productivity advantage from firm-specific knowledge (Caves, 1996; Dunning, 1988; Javorcik, 2014; Javorcik \& Poelhekke, 2017; Rugman \& Verbeke, 2001), are more likely than domestic firms to pay a wage premium to retain their employees (Fosfuri et al., 2001; Glass \& Saggi, 1999, 2002; Globerman et al., 1994).

Other efficiency wage mechanisms leading to an MNE wage premium include search frictions: due to relatively limited local networks and knowledge of the local labor market, MNEs may have to pay more to identify and attract good workers (Hijzen et al., 2013; Lipsey \& Sjöholm, 2004). MNEs may also be inclined to use better pay to motivate employees to overcome problems arising from the different legal and cultural traditions of their home country, or to attract and retain employees who possess specific qualities to bridge these differences (Hijzen et al., 2013). Prior studies have shown that MNEs are indeed able to attract these employees from their local counterparts through higher wages (Fortanier \& Van Wijk, 2010). Another possible explanation offered by extant research is that, as firms share part of their profits with their employees ("rent-sharing"), an MNE wage premium can be expected because MNEs are more profitable than domestic firms while facing the same rent-sharing preferences of local employees (Budd, Konings, \& Slaughter, 2005; Dunning, 1988; Egger \& Kreickemeier, 2013; Helpman, Itskhoki, \& Redding, 2010; Martins \& Yang, 2015; Rugman \& Verbeke,
2001). Building on the above, we can therefore conclude that a substantial body of empirical work has shown that, all else equal, MNEs are expected to pay a higher wage than domestic firms.

However, while research in economics has offered consistent support in favor of the existence of the MNE wage premium, we recognize several limitations of the reviewed studies. First, we lack insight into the distributional effects associated with MNEs' presence in the host-country context, especially in relation to three key employees' characteristics: their gender, experience, and immigrant status. Second, the literature has to date predominantly focused on individual country settings (or at most a small number of countries in comparative analyses), limiting our understanding of the important role of host country-level heterogeneities in determining how MNEs pay their employees and thus influencing the magnitude of their wage premia. Third, from a methodological standpoint, the multilevel nature of the phenomenon under scrutiny has been neglected. Whereas IB scholars have emphasized the importance of accounting for the possible variation in estimated effects at different levels of analysis (Andersson, Cuervo-Cazurra, \& Nielsen, 2014; Peterson, Arregle, \& Martin, 2012) - i.e., considering differences at the firm, industry, and country level - international economics studies have not embraced a multilevel approach to study MNEs' wage premia in host countries.

We argue that these drawbacks have prevented us from gaining insights into how MNEs' distributional effects interplay with country-level (institutional) heterogeneities, thus limiting our understanding of this phenomenon. The next subsections address the main theoretical arguments with regard to expected wage differentials and important host country-level contingencies, leading to a set of hypotheses. As pointed out in the Introduction, we emphasize that the theoretical development that follows focuses on foreignowned subsidiaries of MNEs versus purely domestic firms (which have neither activities in foreign countries nor any foreign ownership), thus enabling us to develop (and subsequently test) hypotheses on distributional effects that are unique to MNEs. ${ }^{2}$ The methodological drawback mentioned above (as third limitation of studies in economics) will be discussed further in the subsequent section when presenting the data and the mixed effects model analysis used to test our hypotheses. 


\section{MNEs' Distributional Effects}

\section{The gender wage gap}

An important key source of inequality is the gender wage gap, which corresponds, all else equal, to a lower wage paid to females compared to males. Prior research has shown that such a gap exists, although in varying degrees, in almost every country in the world (Blau \& Kahn, 2017; ILO, 2018). For considering this macro-level phenomenon at the firm level, and specifically for MNEs (as compared to domestic firms), it is important to note that human resource management (HRM) systems and practices are commonly standardized across MNEs' subsidiaries. This standardization may stem from the need to realize an effective and efficient control of the organization in executing MNEs' global strategy (Chung, Park, Lee, \& Kim, 2015; Edwards $\&$ Kuruvilla, 2005), to ensure that similar systems are followed as other MNEs in view of international competitive pressures (Ferner, Quintanilla, \& Varul, 2001), or even stand out if one perceives HRM as constituting an FSA (Kim, Pathak, \& Werner, 2015; Rugman \& Verbeke, 2003) or as supporting the exploitation of an FSA (Taylor, Beechler, \& Napier, 1996). Prior research has therefore suggested that internally transferred HRM in MNEs' subsidiaries is likely to be more formalized and standardized compared to the ones adopted in domestic firms (Björkman, Fey, \& Park, 2007; Mellahi, Demirbag, Collings, Tatoglu, \& Hughes, 2013; Pudelko \& Harzing, 2007).

A formal structure guiding wage levels and increases linked to objective output criteria can be expected to reduce the likelihood of a gender wage gap compared to a situation in which, for example, one individual ('traditional' male) manager has discretion to decide about payments and promotions. While this may have to do with genderspecific preferences and managers' gender, both areas in which research has shown male-female manager differences (e.g., Abraham, 2017; Festing, Knappert, \& Kornau, 2015), findings overall seem to suggest thus far that managerial 'biases' negatively affecting the allocation of wages/resources to women reflect broader social or corporate cultural beliefs (Artz, Goodall, \& Oswald, 2018; Elvira \& Graham 2002; England, 2017). These might include perceptions of females being less productive than males (England, 2017), undervaluation of work done by women (Elvira \& Graham 2002; Festing et al., 2015), or (socialized) negative feelings that are aroused when women ask or negotiate for higher wages (Artz et al., 2018). Standardized systems that aim to objectivize and contain formalized criteria for performance evaluation and rewards, as used in MNEs, reduce managerial discretion and thus the potential of biases affecting wages (Abraham, 2017; Elvira \& Graham, 2002; Festing et al., 2015); they might also offer less room for biases regarding the role and characteristics of parents which lead to the so-called 'motherhood penalty' and/or 'fatherhood premium', two phenomena both reported by social scientists (Budig \& England, 2001; Budig \& Hodges, 2010; Fuller \& Cooke, 2018; Killewald \& García-Manglano, 2016).

In addition to formalization, there is another factor that leads us to expect that the female wage gap will be lower in MNEs than in domestic firms. As pointed out by Maggioni, Santangelo, and Koymen-Ozer (2019), ownership specificities represent critical factors influencing firms' sensitivity to reputational and operating considerations. Specifically, the authors focus on the distinction between foreign versus local owners, positing that foreigners tend to face more severe reputational and operating costs associated with labor standards than locals. As already highlighted by Kostova and Zaheer (1999), foreign investors are expected to do more than local ones in building their reputation and goodwill in the host country. They will also be more vulnerable to reputational and legitimacy concerns, given their larger public exposure, in case of labor standards infringements. Therefore, as mentioned above, MNEs have become rather active in disclosing information, including on equal opportunity and diversity, and adhere to global guidelines containing these principles, for example, issued by the OECD and UN agencies, leading to upward harmonization (e.g., Einwiller, Ruppel, \& Schnauber, 2016; Fortanier, Kolk, \& Pinkse, 2011). Considering the above, we therefore expect MNEs to be more sensitive to gender equality than domestic firms. Accordingly, we formulate the following hypothesis:

Hypothesis 1: All else equal, the gender wage gap is smaller in MNEs than in domestic firms.

\section{The experience wage premium}

The experience wage premium refers to the higher wages paid to employees with greater (versus lower) experience (Katz \& Revenga, 1989). There are two mechanisms through which the reward for experience is expected to be different between MNEs and 
domestic firms. First, MNEs need to pay a premium to attract and retain experienced employees with the specific skills and competences necessary to work in an MNE's subsidiary in the often complex context of an international firm with multiple interests across geographies, and to help the exploitation of FSAs (Collings, Mellahi, \& Cascio, 2019; Guthridge \& Komm 2008; Meyer \& Xin, 2018; Morris, Snell, \& Björkman, 2016; Tarique, Schuler, \& Gong, 2006; Tatoglu, Glaister, \& Demirbag, 2016). Experienced employees who meet the MNE's relatively higher criteria tend to be scarcer because of the greater difficulty to acquire such skills and competences, and thus command a wage premium (Collings et al., 2019; McDonnell, Lamare, Gunnigle, \& Lavelle, 2010; Mellahi \& Collings, 2010). Moreover, to attract entry-level employees (with thus low to no experience) there is less (or even no) need for MNEs to pay a premium given that their brand, reputation, and career opportunities constitute important pull factors; as a result, MNEs are less likely to pay a wage premium for entry-level employees as there is likely no shortage or even an abundance of candidates for entry-level jobs (Ready, Hill, \& Conger, 2008). Thus, MNEs are more likely than domestic firms to pay a wage premium to experienced employees.

Second, and directly related to the above, MNEs invest relatively more in internal talent development (Meyer \& Xin, 2018; Morris et al., 2016; Tatoglu et al., 2016). Their formal HRM systems allow them to monitor the performance of employees throughout the company, helping to select and develop those with the most potential to take on larger responsibilities within the MNE network (Mäkelä, Björkman, \& Ehrnrooth, 2010). MNEs' firm-specific knowledge and resources allow them to train these talents more extensively and effectively (Chang, Chung, \& Moon, 2013; Görg, Strobl, \& Walsh, 2007). Concurrently, thanks to MNEs' international spread, their employees have greater opportunities to benefit from their growing experience, developing the high-level skills and competences that are crucial for MNEs' success, for instance by leveraging the enhanced exposure to multiple geographies (Bossard \& Peterson 2005; Harzing, 2001; Le \& Kroll, 2017; Li \& Scullion, 2010; Sarabi, Froese, \& Hamori, 2017). In this way, these employees' knowledge of and contribution to MNEs' FSAs accumulate, further increasing the importance of retaining them. As a result, experienced employees working in MNEs' subsidiaries are, in the end, the ones who play a crucial role in helping bridge the distance between home and host countries and execute MNE's strategy globally (Rickley, 2019; Le \& Kroll, 2017). This explains why over the years, and with increasing training and experience, a wage premium can be expected for such employees in MNEs compared to domestic firms. This thus leads us to expect the following:

Hypothesis 2: All else equal, the experience wage premium is larger in MNEs than in domestic firms.

\section{The immigrant wage gap}

Besides gender and experience, we also examine MNEs' distributional effects in host countries in terms of the different status and concomitant wage gap for foreign-born compared to locally born employees. While various terms are being used for foreign-born citizens, so-called immigrants are often categorized as "outgroup" members - as defined in social identity theory (see below) - and frequently have an associated lower social status than locals in society and, more specifically, in the workplace. This phenomenon has been widely studied, for example in the US context (Akresh, 2008; Frank, Akresh, \& Lu, 2010), but recent developments, particularly the emergence of vocal populist (political) movements, seem to have increased resentment in a wide range of countries "against outside groups who allegedly pose a threat to the popular will" (Rodrik, 2018, p. 24). In combination, these factors have been shown to often lead to lower pay for immigrant workers (Frank et al., 2010, Harrison, Harrison, \& Shaffer, 2019; The Economist, 2018). ${ }^{3}$

According to social identity theory, self-image is not only derived from personal identity but also from a person's identification with groups, in which a person self-categorizes to denote her/his sense of belonging (Tajfel \& Turner, 1986; Turner, 1982). A substantial body of research has shown that even trivial group categorizations (e.g., the preference for an abstract painter in Tajfel's (1978) experiments) can lead to favoritism and more positive attitudes towards "ingroup" members; and discrimination, stereotyping, and reduced tolerance for mistakes or violations of social rules towards "outgroup" members, also within organizations (Haslam \& Ellemers, 2005; Hogg \& Terry, 2000; Reiche, Harzing, \& Pudelko, 2015). Although identification with a group can be based on a myriad of factors, studies find that cultural background, race, and ethnicity are particularly salient 
cues that influence whether people categorize themselves and others in "ingroup" versus "outgroup" in an organizational context (Hogg \& Terry, 2000; Jiang, Chua, Kotabe, \& Murray, 2011).

Research has shown that foreign-born employees are likely categorized in the "outgroup" in organizations, and consequently perceived as less competent, trustworthy, and cooperative than locally born employees (Brewer, 1979; Harrison et al., 2019; Tajfel, 1982). For example, as found by Tsui and O'Reilly (1989), subordinates from "outgroup" demographic minorities may, on average, compared to "ingroup" subordinates (from the demographic majority), receive worse performance evaluations by "ingroup" managers. Research has also suggested that the negative effects of group categorization are especially pronounced in those organizations where the workforce is primarily composed of "ingroup" locally born employees (Brewer, 1996; Brewer, Von Hippel, \& Gooden, 1999; McDonald, Keeves, \& Westphal, 2018) and organizational values on how to act, dress, and interact are heavily based on local societal norms (Hogg \& Terry, 2000; Reiche et al., 2015). These mechanisms are of particular relevance in the IB context. For instance, Campbell, Eden, and Miller (2012) elaborate inter alia on the related notion of empathy - i.e., the feeling resulting from an individual imagining her- or himself to be in another person's position - to posit that smaller cultural distance, associated with higher perceived similarity, increases the likelihood of an empathetic response, which also translates into monetary contributions.

Building on the above, and given MNEs' multicountry embeddedness, we expect that in MNE subsidiaries, foreign-born employees are less likely to be perceived as "outgroup" members than in purely domestic firms whose activities are exclusively confined to the geographic borders of their home country. This is because MNEs have been shown to actively support the creation of a firmlevel "ingroup" social identity and prevent the prevalence of national culture or ethnicity-based "ingroups" (Reiche et al., 2015). MNEs need to effectively filter and interpret the knowledge that is continuously transferred to them by their headquarters (and/or other geographically dispersed subsidiaries) and adapt this knowledge to the local setting, which requires a nuanced understanding of the different contexts, languages, and cultures characterizing the multiple organizational units (Achcaoucaou, Miravitlles, \& León-Darder, 2014;
Figueiredo, 2011; Meyer, Mudambi, \& Narula, 2011; Vora et al., 2019). Thus, the creation of a firm-level "ingroup" social identity that goes beyond geographical boundaries facilitates the absorption and adaptation of knowledge by its international subsidiaries (Reiche et al., 2015). That an MNE creates such a firm-level social identity that is less sensitive to the geographic location of its activities is expected to weaken the social differentiation between foreign-born and locally born employees in its subsidiaries, independent from their role within the organization.

Relatedly, MNEs tend to rely on a relatively more diverse workforce (Rosenzweig, 1998; Tatoglu et al., 2016) and foster the development of organizational values reflecting their pluralistic multicultural context spanning beyond the subsidiary location, as MNE subsidiaries are embedded in their headquarters' (international) networks as well as in their (host-)country context (Reiche et al., 2015; Rosenzweig, 1998). The social identification associated with being a foreign- versus locally born employee is therefore likely to be less pronounced in an MNE subsidiary than in a purely domestic firm in which the separation between what can be labeled as "foreign" versus "local" tends to be more marked and thus a more likely source of group identification. Based on these considerations, our expectation is that, all else equal, the wage differential between immigrants and local workers is smaller in MNEs compared to domestic firms. Accordingly, we formulate the following hypothesis:

Hypothesis 3: All else equal, the immigrant wage gap is smaller in MNEs than in domestic firms.

\section{The Effect of Host-Country's Institutional Development}

Institutional environments play a fundamental role in shaping MNEs' strategies and behaviors (e.g., Peng, Wang, \& Jiang, 2008). Traditionally, institutions have been viewed as affecting MNEs in a multitude of ways, for example in their performance (Brouthers, 2013; Chacar, Newburry, \& Vissa, 2010; Dau, 2018), governance practices (Aguilera, Judge, \& Terjesen, 2018), the pricing of initial public offerings (Boulton, Smart, \& Zutter, 2010), CSR reporting (Kolk \& Fortanier, 2013; Marano, Tashman, \& Kostova, 2017), the likelihood of successfully completing acquisitions (Dikova, Sahib, \& Van Witteloostuijn, 2010), and the 
transfer of organizational practices (Kostova \& Roth, 2002). As the level of institutional development is multi-dimensional (e.g., Young, Welter, \& Conger, 2018), we consider specifically those components that seem most relevant for our study: the strength of property rights protection, because it safeguards firms from spillovers (e.g., Zhao, 2006), and labor regulation, which influences firms' freedom and flexibility in setting wages (cf. Alvaredo, Chancel, Piketty, Saez, \& Zucman, 2017; Kostova, Roth, \& Dacin, 2008). We discuss property rights and labor freedom consecutively below.

\section{Property rights protection}

Property rights protection signals stronger institutional environments with legal, formal guarantees and concomitant systems (Young et al., 2018). The risk of firm-specific knowledge and property being appropriated by others is highest when institutional constraints are few or weak (Berry, 2017; Pisani \& Ricart, 2018; Sugathan \& George, 2015; Zhao, 2006), when the quality of contract enforcement is weak (Acemoglu \& Johnson, 2005) or when judicial systems are not effective (Jandhyala, 2013). In such a situation, imitative local firms can learn about an MNE's firm-specific knowledge by hiring key employees and working with supplier firms of the MNE (Javorcik, 2004). When countries lack strong institutional protection for property rights, the risk of spillovers of firm-specific knowledge is especially high (Berry, 2017; Pisani \& Ricart, 2018; Zhao, 2006). These countries are characterized by poorly conceived and ineffectively enforced employment contracts and property rights (Li \& Qian, 2013; Meyer \& Peng, 2016), with a need for MNEs to rely on relationships rather than institutions (Batjargal, 2007; Chen, Chen, \& Huang, 2013; Meyer \& Peng, 2016; Parmigiani \& Rivera-Santos, 2015; Smith, Torres, Leong, Budhwar, Achoui, \& Lebedeva, 2012). Employee confidentiality agreements and non-compete clauses, which are commonly used in developed countries to prevent knowledge spillovers (Cheng, Zhang, \& Zhou, 2018), are therefore less likely to be an effective measure in these countries, and the need to prevent employees from leaving by building good relationships with them are thus more pressing for MNEs (cf. Berry, 2017). Based on the above, we formulate the following hypothesis:

Hypothesis 4a: All else equal, the greater the host country's property rights protection, the smaller the MNE wage premium.

\section{Labor freedom}

Labor freedom reflects how flexible (as opposed to rigid) a country's labor market is, considering various aspects of its legal and regulatory framework, including standards for minimum wages, laws inhibiting layoffs, restrictions on hiring and firing employees, and the administrative and financial consequences of dismissals such as severance requirements (Alimov, 2015; Miller, Holmes, \& Feulner, 2013; Young et al., 2018). Wages are strongly institutionally constrained by labor regulations. In a highly regulated labor market, MNEs thus have little discretion in setting wages and executing global compensation and wage-bargaining practices (Farndale et al., 2017). Moreover, labor regulations may also include collective bargaining agreements and bonus caps, which have been shown to drive a convergence in wages in developed countries (Alvaredo et al., 2017). Furthermore, in an environment characterized by a highly regulated labor market, stronger pressures for legitimacy lead to isomorphism, i.e., the convergence of firm behavior (Kostova et al., 2008; Meyer \& Peng, 2016). In such stakeholder-mandated settings (Testa, Boiral, \& Iraldo, 2018; Verbeke, 2009), firms are faced with, for example, NGO, customer and media scrutiny (Bapuji et al., 2018; Conyon, Fernandes, Ferreira, Matos, \& Murphy, 2011; Kolk, 2010), and often a formal role for trade unions and/or work councils, and concomitant bargaining mechanisms (Barrows, 2017). They further limit the possibility for MNEs to set wages and thus deviate from domestic firms. Based on these considerations, we hypothesize:

Hypothesis 4b: All else equal, the greater the host country's labor freedom, the larger the MNE wage premium.

\section{EMPIRICAL ANALYSIS}

\section{The Sample}

To test the hypothesized relationships, we rely on the "WageIndicator", which provides data on the individual characteristics and employment conditions of employees across a wide variety of firms, industries, and countries. The "WageIndicator" project was initiated in the Netherlands in 1999 and is managed by the WageIndicator Foundation, a coalition of AIAS, the University of Amsterdam Institute for Labour Studies, and local trade unions in 92 countries, which aims to improve labor 
market access and transparency. Previous studies have compared wages reported in WageIndicator samples and the distribution of samples across industries to the data of national statistics offices and found no inconsistencies (Fortanier, 2008; Tijdens, Beblavý, \& Thum-Thysen, 2018). A further, extensive explanation of the dataset, which is very suitable for our purposes, and its possibilities and limitations, can be found in the Appendix. We took the most recent surveys available, which were the ones completed between January 1, 2013 and December 31, 2014. ${ }^{4}$ These surveys were either filled out online, on paper, or completed with the help of an interviewer (in countries with low literacy rates). We used data from the 13 countries with the most respondents for which data on institutional development and cultural traits were available, namely Argentina, Belgium, Brazil, Czech Republic, Germany, India, Indonesia, Mexico, The Netherlands, Russia, Slovakia, South Africa, and Ukraine. The total sample includes 40,258 employees, with each country contributing at least 2100 respondents. The employees work in 32 narrowly defined industries that include agriculture (e.g., forestry), manufacturing (e.g., pharmaceutics), and services (both private, e.g., real estate, and public sectors). Of the respondents, $58.5 \%$ were male and the average age in the sample was 36 years $(\mathrm{SD}=$ 11 years) at the time of completion of the survey (for a detailed description of the dataset, including information on representativeness, see the Appendix).

\section{Methodology}

Through econometric analysis, we first aimed to estimate the effect of being an employee of an MNE (versus a domestic firm) on wage to determine the existence of the MNE wage premium in our empirical setting. For estimating such effect, a multilevel mixed effects model is required as each individual employee (level one) is hierarchically nested within only one industry (level two) and country (level three) and we expect level two and level three variables to predict the means of the level one variables (Peterson et al., 2012). This approach allows us to account for observable and unobservable characteristics influencing wages that originate at the employee, industry, and country level (Briscoe \& Joshi, 2017). In particular, we used the mixed command available in Stata 14, thereby allowing the random intercept and MNE coefficient to vary at the employee, industry, and country level (Andersson et al., 2014).
To determine whether employee-level variables did vary significantly between industries, we calculated the ICC. The industry ICC was 0.39 , which implies that $39 \%$ of the total variance in wages is at the industry level, therefore corroborating the need to use a multilevel model that includes the industry level in our estimation. The country ICC was $0.35-$ i.e., $35 \%$ of the total variance in wages is at the country level - therefore confirming the need to include a separate country level in our analysis as well. A relevant aspect of the dataset used is that individual employees are also hierarchically nested in firms (which are then nested in industries and countries). However, to ensure anonymity, the individual employee surveys are not linked to specific firms.

To establish whether the inclusion of the firm level was necessary in our estimation, we combined variables on firm characteristics (firm size, industry, country, typology - MNE versus domestic firm and private/public sector) and thus identified groups of respondents that could potentially work for the same firm. As a result of this calculation, we obtained that the average (firm) group size was only 2.5. Moreover, when calculating the firm-level ICC based on this firm-level grouping, we obtained 0.11 , thus confirming that only $11 \%$ of the total variance in wages is at the firm level. As 0.11 is lower than 0.15 - considered to be the threshold for high ICCs (Peterson et al., 2012) - this result corroborated that the inclusion of an additional firm level was not needed in our estimation. As a result, in view of the fact that in our empirical setting we are not able to identify individual firms with certainty and the ICC obtained based on the above-mentioned firm-level grouping remains low, we restricted our focus to the industry and country levels in our estimations. Further analyses, aimed at determining whether the inclusion of a firm level may influence our results (reported in the robustness checks subsection below), lend additional support to our conclusions.

We estimated a series of multilevel models to test our hypotheses. First, we constructed a baseline model with Wage as dependent variable and including only the control variables and a dummy variable (MNE) separating employees working for an MNE versus a domestic firm, so as to estimate the direct effect of $M N E$ on wages and thus determine the existence of the MNE wage premium in our setting. We then tested three models including interaction terms between MNE and the employee's gender (Female), level of experience (Experience), 
and immigrant status - thus comparing the country of birth versus the country of work (Immigrant) - to precisely test MNEs' distributional effects as postulated in Hypotheses 1, 2, and 3. In order to test the moderating effect of the hostcountry level of institutional development as posited in Hypotheses $4 \mathrm{a}$ and $4 \mathrm{~b}$, we included two variables that specifically measure the level of property rights protection (Property Rights) and labor freedom (Labor Freedom) of the host country and interacted them with MNE.

To test whether the variances of the slopes of the variables in the random models were significantly different from zero, we used likelihood ratio tests. Because variances cannot be lower than zero, we followed standard practice and divided $p$ values by two. Variance-covariance between the random effects was assumed to be unstructured, i.e., not zero (Rabe-Hesketh \& Skrondal, 2008).

\section{Variables}

In this subsection, we provide a detailed description of the variables used in our analysis.

\section{Dependent variable}

For all models, our dependent variable Wage corresponds to the employee's gross hourly wages in US dollars at purchasing power parity (PPP). The mean hourly wage (at PPP) was $\$ 12.53$ with a standard deviation of $\$ 2.78$. As data were skewed, we performed a $\log$ transformation to approximate a normal distribution.

\section{Explanatory variable}

We measure whether an employee is employed by an MNE with a dummy variable $M N E(1=\mathrm{em}$ ployed by a foreign-owned subsidiary of an MNE; $0=$ employed by a purely domestic firm which has neither activities in foreign countries nor any foreign ownership). This dummy variable was constructed from the WageIndicator survey question asking whether the respondent is employed by a multinational firm and thus allowed us to identify all employees who worked for an MNE as opposed to a domestic firm.

\section{Moderating variables - distributional effects}

To empirically determine whether and, if so, how the gender wage gap, experience wage premium, and immigrant wage gap vary in MNEs versus domestic firms, we use three moderating variables. Gender is measured by a dummy variable (Female: $0=$ male, $1=$ female); experience is measured through a combined variable of the employee's age and work experience (factor Eigenvalue $=1.26$; Cronbach's alpha $=0.80$ ); the immigrant status by a dummy variable (Immigrant) that scores 0 if the employee's country of birth corresponds to the country of work and 1 if the surveyed employee is working in a country that is not her/his country of birth.

\section{Moderating variables - host-country institutions}

Following the recent study by Young et al. (2018), we draw the moderating variables from the Heritage Index of Economic Freedom (HFI), also known as the Index of Economic Freedom or EFI (Miller, Kim, \& Roberts, 2019). ${ }^{5}$ There are three other commonly used measures for institutional development - i.e., the Political Constraints Index, the Corruption Perception Index, and the Worldwide Governance Indicators - but they are similar and highly correlated to the HFI as their correlation coefficients vary between 0.89 and 0.94 (Garrido, Gomez, Maicas, \& Orcos, 2014). This result corroborates the notion that these indices measure the same underlying concept. The HFI consists of ten variables measuring rule of law, regulatory efficiency, open markets, and limited government; it has been used in previous research as a measure of the level of institutional development and strength of market-supporting institutions of a given country (e.g., Gubbi, Aulakh, Ray, Sarkar, \& Chittoor, 2010; Kalasin, Dussauge, \& Rivera-Santos, 2014; Marano, Arregle, Hitt, Spadafora, \& Van Essen, 2016; Mauri, Song, \& Neiva de Figueiredo, 2017; Meyer \& Sinani, 2009). To operationalize our key variables of interest that allow us to test for the moderating effects of the host country's level of property rights protection and labor freedom, we built on the two corresponding HFI variables and constructed the following variables:

Property Rights measures the degree to which a country's legislation protects both physical and intellectual property and investments, and the degree to which these laws are enforced in case of violation. Scores are calculated by using five subfactors regarding physical, intellectual, and land property rights, risk of expropriation, and strength of investor protection. Higher scores represent greater legal protection from theft, counterfeiting, or expropriation of firm (intellectual) property.

Labor Freedom measures the flexibility of a country's labor market and labor laws. Scores are calculated by using seven sub-factors regarding minimum wages, flexibility in hiring and firing 
employees, rigidity of working hours, and the labor force participation rate. Higher scores indicate a greater flexibility for firms in setting wages and working conditions for their employees (Miller et al., 2019).

\section{Control variables - host-country culture}

The control variables measuring national culture are drawn from Hofstede's (1980) dimensions of culture. Out of the many measures for national culture (e.g., House, Hanges, Javidan, Dorfman, \& Gupta, 2004; Trompenaars, 1993), Hofstede's dimensions are commonly used, despite the limitations (Beugelsdijk, Kostova, \& Roth, 2017; Kirkman, Lowe, \& Gibson, 2017), and they are suitable for our purposes. Moreover, countries' relative (to other countries) scores have been found to be stable over time (Beugelsdijk, Maseland, \& Van Hoorn, 2015), meaning that while individualism, e.g., has increased, it has done so at a similar rate across all societies. Accordingly, we include in our analysis a country's measure of Individualism, Power distance, Uncertainty Avoidance, and Masculinity, with each dimension being measured on a scale from 0 to 100. Individualism measures the degree to which members of society see themselves as members of a tightly knit group (corresponding to a score of 0 ) or primarily as individuals expected to take care of only their own interests (corresponding to a score of 100). Power Distance measures the degree to which people expect and accept that power is distributed unequally, with a score of 0 indicating members of society prefer an equal distribution of power and inequalities of power need to be justified, and a score of 100 indicating members of society accept hierarchy and large power inequalities without further justification. Uncertainty Avoidance measures the degree to which members of society are comfortable in unstructured situations; a score of 0 indicates that they value practice over principles, while a score of 100 indicates that they prefer a high level of control through inflexible codes of belief, and are intolerant to unorthodox behavior and ideas. Finally, Masculinity measures the degree to which members of society prefer achievement over nurture, with a score of 0 indicating a preference for cooperation, modesty and caring, and a score of 100 indicating a preference for competition, success, heroism, assertiveness, and material rewards (Hofstede, 1980).

\section{Control variables - host-country cultural diversity}

We follow the recommendations of Kirkman et al. (2017) and Beugelsdijk et al. (2017) to also consider within-country cultural diversity to further account for cultural differences, as the homogeneity of the cultural values may differ widely. We therefore include Dow, Cuypers, and Ertug's (2016) indices of within-country Language Diversity and Religious Diversity in our models. The scales measure the incidence of respectively a country's main languages and religions as a proportion of the total population. These scores are then subtracted from 1 , resulting in a scale from 0 to 1 where 0 represents a completely homogenous culture and 1 a completely heterogeneous one.

\section{Control variable - host-country level of institutional development}

We include the overall score of the HFI, which ranges from 0 to 100, to control for the overall level of institutional development encountered by the MNE in the focal host country (Overall HFI). Accordingly, a higher value of Overall HFI implies a higher level of institutional development and stronger market-supporting institutions (Garrido et al., 2014; Young et al., 2018).

\section{Control variables - employee, firm, and industry levels}

We include the employee's managerial position and education, as well as firm size, and industry import and export intensity as controls in our models. Managerial position (Supervisor) is measured by the number of subordinates of the employee (where $0=$ no supervising role) with wage expected to increase with the number of people supervised (Abraham, 2017; Briscoe \& Joshi, 2017). The control variable Education is based on the employee's ISCED-1997 education level and measured on a scale from 0 (no education) to 6 (upper tertiary education), with an expected higher wage for employees with higher levels of education (Márquez-Ramos, 2018). Firm Size is measured in classes ranging from 0 (self-employed without personnel) to 10 (5000 or more employees) with individuals working for larger firms expected to earn more (Mueller, Ouimet, \& Simintzi, 2017).

At the industry level, we used Export Intensity and Import Intensity as control variables because the extent to which a given industry is exposed to international trade has been shown to affect the wage distribution within that industry (Greenaway \& Kneller, 2007; Rodrik, 2018). We used an 
industry-, not a firm-level control, because trade affects wages in the entire industry through the rationalization and reallocation of labor and production of goods and services (Artuc, Chaudhuri, \& McLaren, 2014; Pavcnik, Blom, Goldberg, \& Schady, 2004). We measured both Export Intensity and Import Intensity as the value-to-GDP ratio (Anderson, 2005) - the ratio between the value of the industry's exports or imports and the industry's total value added:

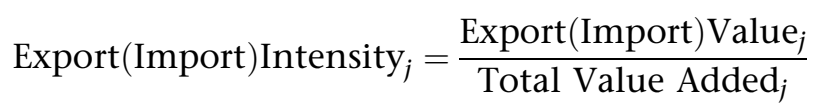

Industry export (import) value was calculated on a two-digit NACE industry level. For agricultural and manufacturing industries, we retrieved trade-related data from the UN Comtrade database on a sixdigit HS industry level, which was then converted to two-digit NACE level using OECD conversion tables. For services, we used the WTO's I-TIP services database as the main source of data. We retrieved the industry value added data from the OECD STAN database for the OECD countries in the sample, and from the UN for the other (nonOECD) countries. The UN data did not specify value added data on a two-digit NACE level for the manufacturing industry, therefore export and import intensities are aggregated to one-digit NACE level for the manufacturing industries of nonOECD countries. Following standard practice in economics studies on the effect of import and export intensity, a time lag between trade-related measures and our dependent variable was introduced as wages are generally sticky and a delayed effect of trade values on wages can therefore be expected (Hall, 2005).

\section{RESULTS}

Table 1 gives an overview of all variables in our models, while Table 2 provides the correlation matrix and the descriptive statistics of the variables employed in our models. We estimated the variance inflation factors (VIF) to check for potential multicollinearity problems. The only issue encountered is the very high correlation between Individualism and Overall HFI $(r=0.84)$, and between Individualism and Power Distance $(r=-0.80)$ in our empirical setting, resulting in high VIFs. We therefore decided to drop Individualism from our model estimations. After excluding Individualism, all VIFs values were well below the severest limit of 5.3 proposed by Hair, Anderson, Tatham, and Black (1998), with the highest being 3.29 for Import Intensity.

\section{Results of the Main Analysis}

To test for the presence of an MNE wage premium in our empirical setting in light of the nested nature of our data, we estimate a multilevel mixed effects regression model analyzing the direct effect of $M N E$ on Wage (model 1 in Table 3):

$$
\begin{aligned}
\text { Wage }_{i j k} & =\alpha_{000}+\beta_{100} \text { Supervisor }_{i j k}+\beta_{200} \text { Education }_{i j k} \\
& +\beta_{300} \text { FirmSize }_{i j k}+\beta_{010} \text { ExportIntensity }_{j k} \\
& +\beta_{020} \text { ImportIntensity }_{j k} \\
& +\beta_{001} \text { PowerDistance }_{k} \\
& +\beta_{002} \text { UncertaintyAvoidance }_{k} \\
& +\beta_{003} \text { Masculinity }_{k} \\
& +\beta_{004} \text { LanguageDiversity }_{k} \\
& +\beta_{005} \text { ReligiousDiversity }_{k} \\
& +\beta_{006} \text { OverallHFI }_{k}+\beta_{400} \text { Female }_{i j k} \\
& +\beta_{500} \text { Experience }_{i j k}+\beta_{600} \mathrm{MNE}_{i j k} \\
& +\pi_{1 j} \mathrm{MNE}_{j k}+\gamma_{1 k} \mathrm{MNE}_{k}+\varepsilon_{i j k}+\zeta_{0 j k}+\eta_{00 k}
\end{aligned}
$$

where $i$ is the individual employee, $j$ is the industry, $k$ is the country and $\varepsilon, \zeta$, and $\eta$ are the error terms.

To test our Hypothesis 1, i.e., the moderating effect of Female, we estimate the following regression model (model 2 in Table 3):

$$
\begin{aligned}
\text { Wage }_{i j k}= & \alpha_{000}+\beta_{100} \text { Supervisor }_{i j k}+\beta_{200} \text { Education }_{i j k} \\
& +\beta_{300} \text { FirmSize }_{i j k}+\beta_{010} \text { Export Intensity }_{j k} \\
& +\beta_{020} \text { Import Intensity }_{j k} \\
& +\beta_{001} \text { Power Distance }_{k} \\
& +\beta_{002} \text { Uncertainty Avoidance }_{k} \\
& +\beta_{003} \text { Masculinity }_{k} \\
& +\beta_{004} \text { Language Diversity }_{k} \\
& +\beta_{005} \text { Religious Diversity }_{k} \\
& +\beta_{006} \text { Overall HFI }_{k}+\beta_{400} \text { Female }_{i j k} \\
& +\beta_{500} \text { Experience }_{i j k}+\beta_{600} \text { MNE }_{i j k} \\
& +\beta_{700} \text { MNE }_{i j k} \times \text { Female }_{i j k}+\pi_{1 j} \mathrm{MNE}_{j k} \\
& +\gamma_{1 k} \mathrm{MNE}_{k}+\varepsilon_{i j k}+\zeta_{0 j k}+\eta_{00 k}
\end{aligned}
$$

Similarly, we test the moderating effects of Experience and Immigrant in models 3 and 4 in Table 3, respectively. To test our Hypothesis 4a, i.e., the moderating effect of Property Rights on the relationship between $M N E$ and Wage, we estimate 
Table 1 Operationalization of key variables

\begin{tabular}{|c|c|c|}
\hline Variable & Operationalization & Source \\
\hline \multicolumn{3}{|l|}{ Dependent } \\
\hline Wage & $\begin{array}{l}\text { Natural logarithm of the employee's hourly wage at } \\
\text { PPP, in US dollars }\end{array}$ & Wagelndicator \\
\hline \multicolumn{3}{|l|}{ Independent } \\
\hline MNE & $\begin{array}{l}\text { A dummy variable indicating whether the employee is } \\
\text { employed by an MNE }(1=\text { yes; } 0=\text { no })\end{array}$ & Wagelndicator \\
\hline \multicolumn{3}{|c|}{ 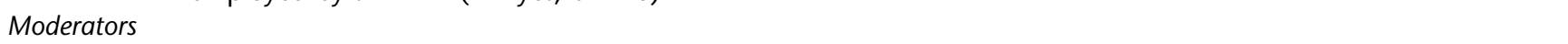 } \\
\hline Female & $\begin{array}{l}\text { A dummy variable indicating whether the employee is } \\
\text { female }(1=\text { yes; } 0=\text { no })\end{array}$ & Wagelndicator \\
\hline Experience & $\begin{array}{l}\text { Combined variable of the employee's age and work } \\
\text { experience in years }\end{array}$ & Wagelndicator \\
\hline Immigrant & $\begin{array}{l}\text { A dummy variable indicating whether the employee is } \\
\text { born outside his/her country of work }(1=\text { yes; } 0=\text { no })\end{array}$ & Wagelndicator \\
\hline $\begin{array}{l}\text { Property } \\
\text { rights }\end{array}$ & $\begin{array}{l}\text { The strength of property right protection in the } \\
\text { employee's country of work [ } 0 \text { (lowest)-100 (highest)] }\end{array}$ & $\begin{array}{l}\text { HFl; more specifically: "Economist Intelligence Unit, Country } \\
\text { Commerce, 2009-2012; U.S. Department of Commerce, } \\
\text { Country Commercial Guide, 2009-2012; U.S. Department } \\
\text { of State, Country Reports on Human Rights Practices, } \\
\text { 2009-2012; and various news and magazine articles" (Miller } \\
\text { et al., 2013, p. 478) }\end{array}$ \\
\hline $\begin{array}{l}\text { Labor } \\
\text { freedom }\end{array}$ & $\begin{array}{l}\text { The degree of labor freedom in the employee's country } \\
\text { of work [0 (lowest)-100 (highest)] }\end{array}$ & $\begin{array}{l}\text { HFl; more specifically: "World Bank, Doing Business 2013; } \\
\text { Economist Intelligence Unit, Country Commerce, } \\
\text { 2009-2012; U.S. Department of Commerce, Country } \\
\text { Commercial Guide, 2009-2012; and official government } \\
\text { publications of each country" (Miller et al., 2013, p. 482) }\end{array}$ \\
\hline \multicolumn{3}{|r|}{ 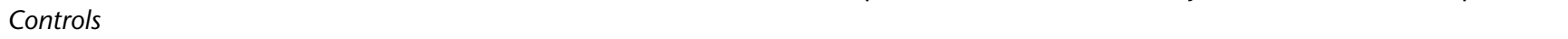 } \\
\hline Supervisor & The number of subordinates of the employee & Wagelndicator \\
\hline Education & $\begin{array}{l}\text { The employee's education level [0 (none)-6 (upper } \\
\text { tertiary)] }\end{array}$ & Wagelndicator \\
\hline Firm size & $\begin{array}{l}\text { The size of the firm the employee works for [0 (self- } \\
\text { employed, no personnel)-10 }(5000+\text { employees })]\end{array}$ & Wagelndicator \\
\hline $\begin{array}{l}\text { Export } \\
\text { intensity }\end{array}$ & $\begin{array}{l}\text { The ratio between the industry export value and the } \\
\text { industry value added, of the industry in which the } \\
\text { employee works }\end{array}$ & UN, OECD, WTO \\
\hline $\begin{array}{l}\text { Import } \\
\text { intensity }\end{array}$ & $\begin{array}{l}\text { The ratio between the industry import value and the } \\
\text { industry value added, of the industry in which the } \\
\text { employee works }\end{array}$ & UN, OECD, WTO \\
\hline Individualism & $\begin{array}{l}\text { The level of individualism in the employee's country of } \\
\text { work [0 (lowest)-100 (highest)] }\end{array}$ & Hofstede (1980) \\
\hline $\begin{array}{l}\text { Power } \\
\text { distance }\end{array}$ & $\begin{array}{l}\text { The level of acceptance of unequally distributed power } \\
\text { in the employee's country of work [0 (lowest)-100 } \\
\text { (highest)] }\end{array}$ & Hofstede (1980) \\
\hline $\begin{array}{l}\text { Uncertainty } \\
\text { avoidance }\end{array}$ & $\begin{array}{l}\text { The level of intolerance towards uncertainty in the } \\
\text { employee's country of work [ } 0 \text { (lowest)-100 (highest)] }\end{array}$ & Hofstede (1980) \\
\hline Masculinity & $\begin{array}{l}\text { The level of masculinity in the employee's country of } \\
\text { work [0 (lowest)-100 (highest)] }\end{array}$ & Hofstede (1980) \\
\hline $\begin{array}{l}\text { Religious } \\
\text { diversity }\end{array}$ & $\begin{array}{l}\text { The level of religious heterogeneity in the employee's } \\
\text { country of work [0 (lowest) }-1 \text { (highest)] }\end{array}$ & Dow, Cuypers, \& Ertug (2016) \\
\hline $\begin{array}{l}\text { Language } \\
\text { diversity }\end{array}$ & $\begin{array}{l}\text { The level of language heterogeneity in the employee's } \\
\text { country of work [0 (lowest)- } 1 \text { (highest)] }\end{array}$ & Dow et al. (2016) \\
\hline Overall HFI & $\begin{array}{l}\text { The aggregate HFI score of the employee's country of } \\
\text { work [0 (lowest)-100 (highest)] }\end{array}$ & $\begin{array}{l}\text { HFI; for a complete list of sources used to compile the Index, } \\
\text { see Miller, Holmes, \& Feulner (2013) }\end{array}$ \\
\hline
\end{tabular}


the following regression model (model 1 in Table 5):

$$
\begin{aligned}
\text { Wage }_{i j k}= & \alpha_{000}+\beta_{100} \text { Supervisor }_{i j k} \\
& +\beta_{200} \text { Education }_{i j k}+\beta_{300} \text { FirmSize }_{i j k} \\
& +\beta_{010} \text { Export Intensity }_{j k} \\
& +\beta_{020} \text { Import Intensity }_{j k} \\
& +\beta_{001} \text { Power Distance }_{k} \\
& +\beta_{002} \text { Uncertainty Avoidance }_{k} \\
& +\beta_{003} \text { Masculinity }_{k} \\
& +\beta_{004} \text { Language Diversity }_{k} \\
& +\beta_{005} \text { Religious Diversity }_{k} \\
& +\beta_{006} \text { Property Rights }_{k}+\beta_{400} \text { Female }_{i j k} \\
& +\beta_{500} \text { Experience }_{i j k}+\beta_{600} \text { MNE }_{i j k} \\
& +\beta_{700} \text { MNE }_{i j k} \times \text { Property Rights }_{k} \\
& +\pi_{1 j} \text { MNE }_{j k}+\gamma_{1 k} \text { MNE }_{k}+\varepsilon_{i j k}+\zeta_{0 j k}+\eta_{00 k}
\end{aligned}
$$

In the same way, we test the moderating effect of Labor Freedom (Hypothesis 4b) in model 2 in Table 5.

\section{Results on MNEs' distributional effects}

Model 1 in Table 3 corresponds to our fully specified model, including all our control and explanatory variables. As expected, we find evidence of an MNE wage premium. MNEs' employees earn significantly more than employees of domestic firms $(p$ value $=0.00)$. All else equal, our findings show that the wage premium associated with working for an MNE is $32.3 \%\left(\mathrm{e}^{0.28}-1\right)$. All control variables, except Import Intensity, are significant and have the expected signs, with, e.g., highly educated employees earning more than lower educated ones on average. Our findings show that industry Import Intensity is not related to Wage in our sample. The positive (i.e., non-zero) variance of the constants at industry and country levels corroborate that industry and country characteristics have a (expected) significant $(p$ value $=0.00$ ) effect on wages and the relationship between $M N E$ and Wage.

Models 2-4 test the moderating effects of Female, Experience, and Immigrant on the relationship between MNE and Wage. First, we note that our results show evidence of both a gender wage gap and experience wage premium in our empirical setting as Female's coefficient is negative and significant while the one of Experience is positive and significant. There is instead no evidence of an immigrant wage gap as Immigrant's coefficient is not significant. With respect to the moderations tested, only the interaction term associated with Experience is significant (and positive; $p$ value $=$ $0.00)$, while the other two associated with Gender and Immigrant are not. Thus, while we find empirical evidence in support of our second hypothesis, our first and third are not supported.

\section{Results on MNEs' distributional effects in developed versus developing countries}

One possible explanation for the above-mentioned result may be that the interactions are antipodal at opposite levels of (institutional) development, and therefore not significantly different from zero on average. We therefore split our sample based on the level of development of the host country, distinguishing between developed and developing countries in our sample (based on the World Bank country classification) ${ }^{6}$ and repeated the analysis; its results are shown in Table 4 .

Models 1 and 2 in Table 4 test Female's moderating effect on the relationship between MNE and Wage in developing and developed countries, respectively. The results indeed show the interaction is antipodal: there is a significant $(p$ value $=$ 0.05) and negative interaction in developing countries, while the interaction is also significant ( $p$ value $=0.03$ ) but positive in developed countries. Thus, while our Hypothesis 1 predicted the gender wage gap to be smaller in MNEs, our results show empirical support for our postulation only in developed countries. Contrary to our expectations, in developing countries the gender wage gap instead turns out to be larger in MNEs. Models 3 and 4 empirically validate that the moderating effect of Experience on the relationship between $M N E$ and Wage is positive and significant ( $p$ value $=$ 0.01 in developing; $p$ value $=0.03$ in developed) in both country groupings, thereby showing support for our Hypothesis 2. Models 5 and 6 show that there is a significant ( $p$ value $=0.09$ ) and positive moderating effect of Immigrant on the relationship between MNE and Wage only in developed countries (it is non-significant in developing countries). Thus, we find evidence in support of our Hypothesis 3 only in our developed-country empirical setting.

Given that our sample is large, the likelihood of finding statistically significant coefficients is high (Ziliak \& McCloskey, 2004). Thus, it is of particular relevance for the purpose of our study to offer an explicit discussion and interpretation of the effect sizes of relevant estimated coefficients (Bettis, Ethiraj, Gambardella, Helfat, \& Mitchell, 2016; 
Table 2 Descriptive statistics and pairwise correlations ${ }^{1}$

\begin{tabular}{|c|c|c|c|c|c|c|c|c|c|c|}
\hline & Mean & SD & (1) & $(2)$ & (3) & (4) & (5) & (6) & (7) & (8) \\
\hline (1) Wage & 2.53 & 1.02 & 1.00 & & & & & & & \\
\hline (2) MNE & 0.13 & 0.33 & 0.18 & 1.00 & & & & & & \\
\hline (3) Female & 0.41 & 0.49 & -0.15 & -0.10 & 1.00 & & & & & \\
\hline (4) Experience & 24.27 & 9.73 & 0.19 & -0.00 & -0.01 & 1.00 & & & & \\
\hline (5) Immigrant & 0.07 & 0.25 & 0.02 & 0.02 & 0.02 & 0.06 & 1.00 & & & \\
\hline (6) Overall HFI & 63.43 & 9.28 & 0.37 & 0.04 & -0.06 & 0.15 & -0.02 & 1.00 & & \\
\hline (7) Property rights & 64.25 & 27.28 & 0.44 & 0.05 & -0.09 & 0.15 & -0.01 & 0.92 & 1.00 & \\
\hline (8) Labor freedom & 54.95 & 14.09 & -0.13 & -0.00 & 0.09 & 0.03 & 0.07 & -0.09 & -0.27 & 1.00 \\
\hline (9) Supervisor & 6.30 & 74.65 & 0.01 & -0.00 & -0.02 & 0.02 & 0.00 & -0.02 & -0.02 & 0.01 \\
\hline (10) Education & 4.26 & 0.80 & 0.00 & 0.07 & 0.04 & -0.11 & 0.02 & -0.32 & -0.35 & 0.26 \\
\hline (11) Firm size & 4.64 & 2.74 & 0.13 & 0.22 & -0.09 & 0.01 & 0.01 & -0.06 & -0.05 & 0.04 \\
\hline (12) Export intensity & 1.10 & 1.71 & 0.13 & 0.12 & -0.07 & 0.02 & 0.01 & 0.18 & 0.21 & 0.05 \\
\hline (13) Import intensity & 0.88 & 1.16 & 0.14 & 0.10 & -0.06 & 0.02 & 0.01 & 0.28 & 0.29 & 0.05 \\
\hline (14) Individualism & 56.50 & 18.39 & 0.51 & 0.03 & -0.00 & 0.19 & 0.07 & 0.84 & 0.78 & 0.15 \\
\hline (15) Power distance & 52.77 & 21.57 & -0.42 & 0.01 & 0.05 & -0.15 & -0.05 & -0.75 & -0.79 & 0.23 \\
\hline (16) Uncertainty avoidance & 65.61 & 15.21 & -0.09 & -0.09 & 0.13 & 0.03 & 0.04 & -0.47 & -0.35 & -0.13 \\
\hline (17) Masculinity & 53.17 & 18.15 & -0.01 & 0.00 & -0.04 & -0.09 & -0.05 & -0.07 & -0.19 & -0.15 \\
\hline (18) Religious diversity & 0.39 & 0.15 & -0.37 & -0.06 & 0.08 & -0.04 & -0.00 & -0.36 & -0.35 & 0.06 \\
\hline \multirow[t]{2}{*}{ (19) Language diversity } & 0.38 & 0.28 & -0.09 & 0.07 & -0.03 & -0.11 & 0.02 & -0.21 & -0.30 & 0.39 \\
\hline & (9) & (10) & $(11)$ & (12) & (13) & (14) & $(15)$ & (16) & (18) & (19) \\
\hline
\end{tabular}

(1) Wage

(2) MNE

(3) Female

(4) Experience

(5) Immigrant

(6) Overall HFI

(7) Property rights

(8) Labor freedom

(9) Supervisor

(10) Education

(11) Firm size

(12) Export intensity

(13) Import intensity

(14) Individualism

(15) Power distance

(16) Uncertainty avoidance

(17) Masculinity

(18) Religious diversity

(19) Language diversity

$$
\begin{array}{rrrrrrrrrrrrr}
1.00 & & & & & & & & & & & \\
0.02 & 1.00 & & & & & & & & & \\
0.03 & 0.15 & 1.00 & & & & & & & & \\
-0.01 & -0.03 & 0.08 & 1.00 & & & & & & & \\
-0.01 & -0.07 & 0.01 & 0.76 & 1.00 & & & & & & \\
-0.03 & -0.30 & -0.04 & 0.29 & 0.34 & 1.00 & & & & & \\
0.02 & 0.39 & 0.04 & -0.17 & -0.20 & -0.80 & 1.00 & & & \\
-0.02 & 0.07 & -0.05 & -0.07 & -0.07 & -0.31 & 0.37 & 1.00 & & \\
0.01 & -0.16 & -0.00 & -0.23 & -0.24 & -0.20 & 0.19 & -0.01 & 1.00 & & \\
0.02 & 0.19 & 0.08 & -0.03 & -0.07 & -0.51 & 0.44 & 0.07 & -0.24 & 1.00 & \\
0.03 & 0.30 & 0.08 & -0.01 & -0.04 & -0.18 & 0.28 & -0.38 & -0.04 & 0.45 & 1.00 \\
\hline
\end{array}
$$

${ }_{1} N=40,258$ observations. Correlations $\geq 0.02$ or $\leq-0.02$ are significant at the 0.01 level.

Meyer, Van Witteloostuijn, \& Beugelsdijk, 2017). To do so, we plotted the results of our interaction tests in Figure 1 below. Specifically, we estimated the average marginal effects of Female, Experience, and Immigrant on the full range of Wage for both MNEs and domestic firms and then accordingly plotted the gender wage gap, experience wage premium, and immigrant wage gap (only for developed countries).
As shown in Figure 1, the gender wage gap is (\$0.55) larger in domestic firms than in MNEs in developed countries - i.e., nearly $25 \%$ larger as it goes from $-\$ 2.23$ to $-\$ 2.78$. However, in developing countries we obtain the opposite result as the (substantially) larger gender wage gap is found for MNEs and not for domestic firms $(-\$ 2.53$ versus $-\$ 1.20$ ). Figure 1 also shows that in both developed and developing countries the experience wage premium is larger in MNEs than domestic firms, being largest for MNEs based in developed 
Table 3 MNE wage premium and the effects of gender, experience, and immigrant status ${ }^{1}$

\begin{tabular}{|c|c|c|c|c|c|c|c|c|c|c|c|c|}
\hline \multirow[t]{4}{*}{ Variables } & \multicolumn{3}{|c|}{ Model 1} & \multicolumn{3}{|c|}{ Model 2} & \multicolumn{3}{|c|}{ Model 3} & \multicolumn{3}{|c|}{ Model 4} \\
\hline & \multicolumn{3}{|c|}{ MNE main effect } & \multicolumn{3}{|c|}{$\begin{array}{l}\text { Female moderating } \\
\text { effect }\end{array}$} & \multicolumn{3}{|c|}{$\begin{array}{c}\text { Experience moderating } \\
\text { effect }\end{array}$} & \multicolumn{3}{|c|}{$\begin{array}{c}\text { Immigrant moderating } \\
\text { effect }\end{array}$} \\
\hline & \multicolumn{3}{|c|}{ DV: Wage } & \multicolumn{3}{|c|}{ DV: Wage } & \multicolumn{3}{|c|}{ DV: Wage } & \multicolumn{3}{|c|}{ DV: Wage } \\
\hline & Coeff. & s.e. & $p$ value & Coeff. & s.e. & $p$ value & Coeff. & s.e. & $p$ value & Coeff. & s.e. & $p$ value \\
\hline \multicolumn{13}{|l|}{ Fixed effects } \\
\hline Supervisor & 0.00 & 0.00 & 0.00 & 0.00 & 0.00 & 0.00 & 0.00 & 0.00 & 0.00 & 0.00 & 0.00 & 0.00 \\
\hline Education & 0.29 & 0.01 & 0.00 & 0.29 & 0.01 & 0.00 & 0.29 & 0.01 & 0.00 & 0.28 & 0.01 & 0.00 \\
\hline Firm size & 0.06 & 0.00 & 0.00 & 0.06 & 0.00 & 0.00 & 0.06 & 0.00 & 0.00 & 0.05 & 0.00 & 0.00 \\
\hline Export intensity & 0.02 & 0.01 & 0.00 & 0.02 & 0.01 & 0.00 & 0.02 & 0.01 & 0.00 & 0.02 & 0.01 & 0.00 \\
\hline Import intensity & 0.01 & 0.01 & 0.40 & 0.01 & 0.01 & 0.40 & 0.01 & 0.01 & 0.38 & 0.00 & 0.01 & 0.91 \\
\hline Power distance & -0.02 & 0.01 & 0.00 & -0.02 & 0.01 & 0.00 & -0.02 & 0.01 & 0.00 & -0.02 & 0.00 & 0.00 \\
\hline Uncertainty avoidance & 0.01 & 0.01 & 0.09 & 0.01 & 0.01 & 0.09 & 0.01 & 0.01 & 0.09 & 0.01 & 0.01 & 0.02 \\
\hline Masculinity & 0.01 & 0.01 & 0.10 & 0.01 & 0.01 & 0.10 & 0.01 & 0.01 & 0.10 & 0.01 & 0.00 & 0.06 \\
\hline Religious diversity & -0.89 & 0.47 & 0.06 & -0.89 & 0.47 & 0.06 & -0.88 & 0.47 & 0.06 & -0.71 & 0.44 & 0.11 \\
\hline Language diversity & 0.44 & 0.29 & 0.14 & 0.44 & 0.29 & 0.14 & 0.44 & 0.29 & 0.14 & 0.29 & 0.28 & 0.30 \\
\hline Overall HFI & 0.02 & 0.01 & 0.05 & 0.02 & 0.01 & 0.05 & 0.02 & 0.01 & 0.05 & 0.03 & 0.01 & 0.01 \\
\hline Female & -0.17 & 0.01 & 0.00 & -0.17 & 0.01 & 0.00 & -0.17 & 0.01 & 0.00 & -0.18 & 0.01 & 0.00 \\
\hline Experience & 0.02 & 0.00 & 0.00 & 0.02 & 0.00 & 0.00 & 0.02 & 0.00 & 0.00 & 0.02 & 0.00 & 0.00 \\
\hline Immigrant & & & & & & & & & & -0.00 & 0.02 & 0.90 \\
\hline MNE & 0.28 & 0.06 & 0.00 & 0.28 & 0.06 & 0.00 & 0.19 & 0.07 & 0.01 & 0.25 & 0.06 & 0.00 \\
\hline MNExFemale & & & & -0.00 & 0.02 & 0.90 & & & & & & \\
\hline MNExExperience & & & & & & & 0.00 & 0.00 & 0.00 & & & \\
\hline MNExImmigrant & & & & & & & & & & 0.03 & 0.04 & 0.53 \\
\hline Constant & 0.15 & 0.97 & 0.88 & 0.15 & 0.97 & 0.88 & 0.15 & 0.97 & 0.88 & -0.39 & 0.95 & 0.68 \\
\hline \multicolumn{13}{|l|}{ Random effects } \\
\hline$\sigma^{2} \mathrm{MNE}$ & 0.01 & 0.01 & 0.00 & 0.01 & 0.01 & 0.00 & 0.01 & 0.01 & 0.00 & 0.01 & 0.01 & 0.00 \\
\hline$\sigma^{2}$ Constant & 0.03 & 0.00 & 0.00 & 0.03 & 0.00 & 0.00 & 0.03 & 0.00 & 0.00 & 0.03 & 0.00 & 0.00 \\
\hline \multicolumn{13}{|l|}{ Country level } \\
\hline$\sigma^{2} \mathrm{MNE}$ & 0.04 & 0.02 & 0.00 & 0.04 & 0.02 & 0.00 & 0.05 & 0.02 & 0.00 & 0.03 & 0.02 & 0.00 \\
\hline$\sigma^{2}$ Constant & 0.06 & 0.03 & 0.00 & 0.06 & 0.03 & 0.00 & 0.06 & 0.02 & 0.00 & 0.05 & 0.02 & 0.00 \\
\hline Number of observations & 40,258 & & & 40,258 & & & 40,258 & & & 35,976 & & \\
\hline $\begin{array}{l}\text { Number of groups } \\
\text { (industry) }\end{array}$ & 332 & & & 332 & & & 332 & & & 301 & & \\
\hline $\begin{array}{l}\text { Number of groups } \\
\text { (country) }\end{array}$ & 13 & & & 13 & & & 13 & & & 12 & & \\
\hline Wald $\chi^{2}$ & 6336.61 & & 0.00 & 6336.67 & & 0.00 & 6346.41 & & 0.00 & 6199.02 & & 0.00 \\
\hline $\operatorname{LR} \chi^{2}$ & 4022.50 & & 0.00 & 4013.20 & & 0.00 & 4021.83 & & 0.00 & 2041.37 & & 0.00 \\
\hline
\end{tabular}

1 Due to missing values the sample that includes the Immigrant variable is smaller, with one country (India) completely missing. Thus, we did not include this variable as control in models 1-3. As a robustness check, we repeated models $1-3$ including Immigrant and all main results hold. The outputs of these additional analyses are available upon request.

countries (\$6.93). Finally, in relation to the immigrant wage gap in developed countries, we find that there is a very small wage difference in domestic firms (\$0.21), while for MNEs there is evidence in support of an immigrant wage premium (\$1.72). Overall, these results corroborate the economic relevance of the moderations obtained.

\section{Results on the moderating roles of host-country's institutional development}

Models 1 and 2 in Table 5 test the moderating effects of Property Rights and Labor Freedom on the relationship between MNE and Wage. Model 1 shows the negating moderating effect of Property Rights, therefore empirically validating Hypothesis 4a in our setting; Model 2 shows instead no significant interaction when focusing on Labor 


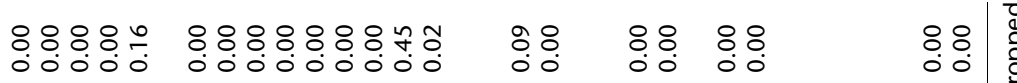

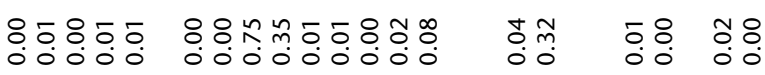

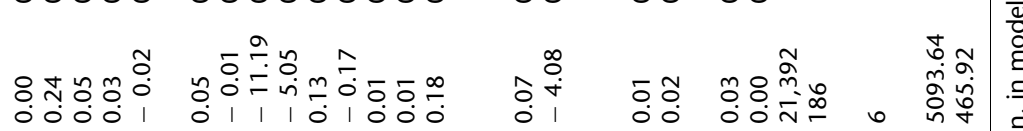

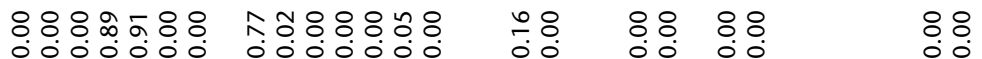

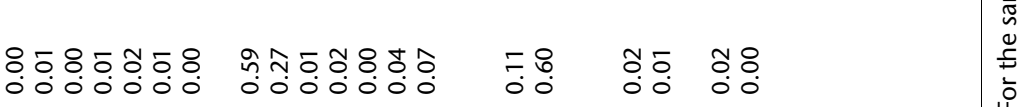

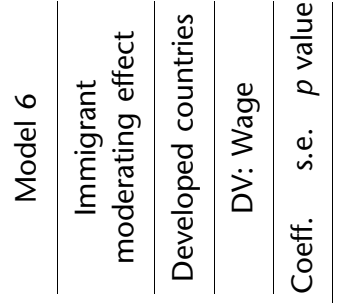

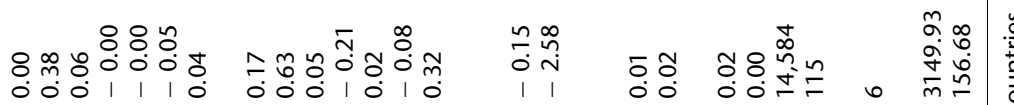

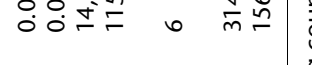

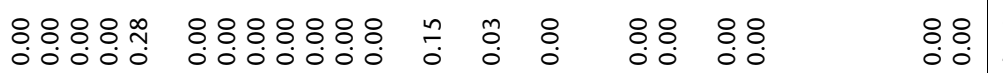

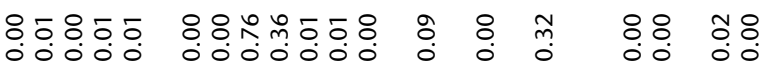

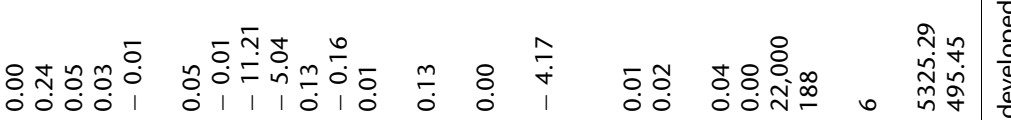

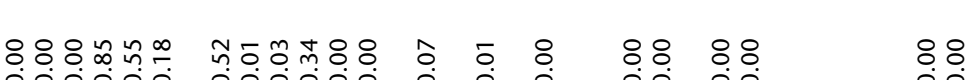

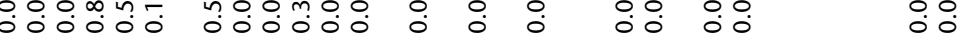

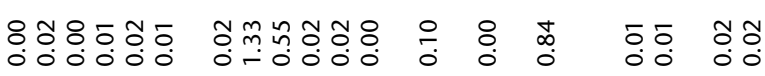

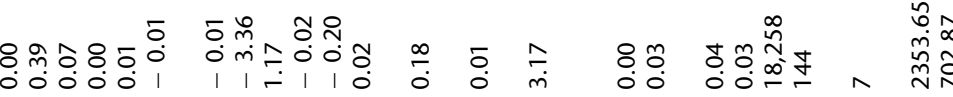

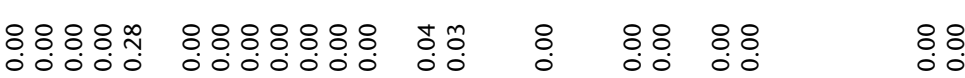

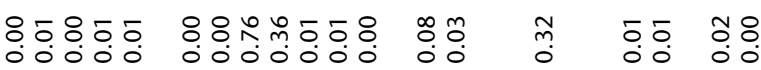

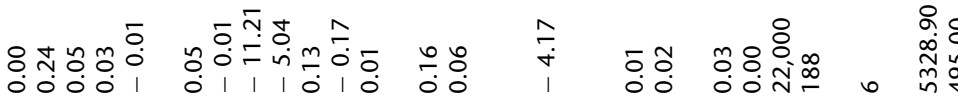

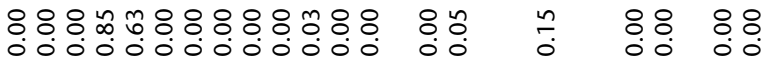

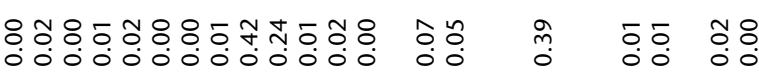

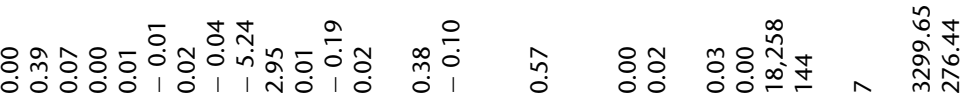

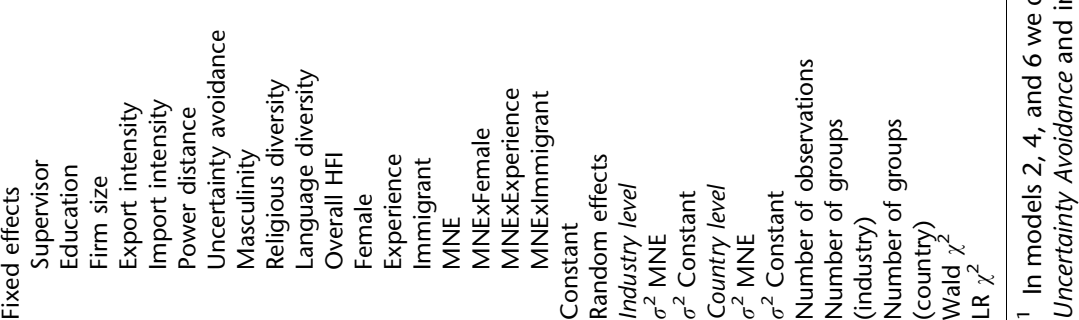




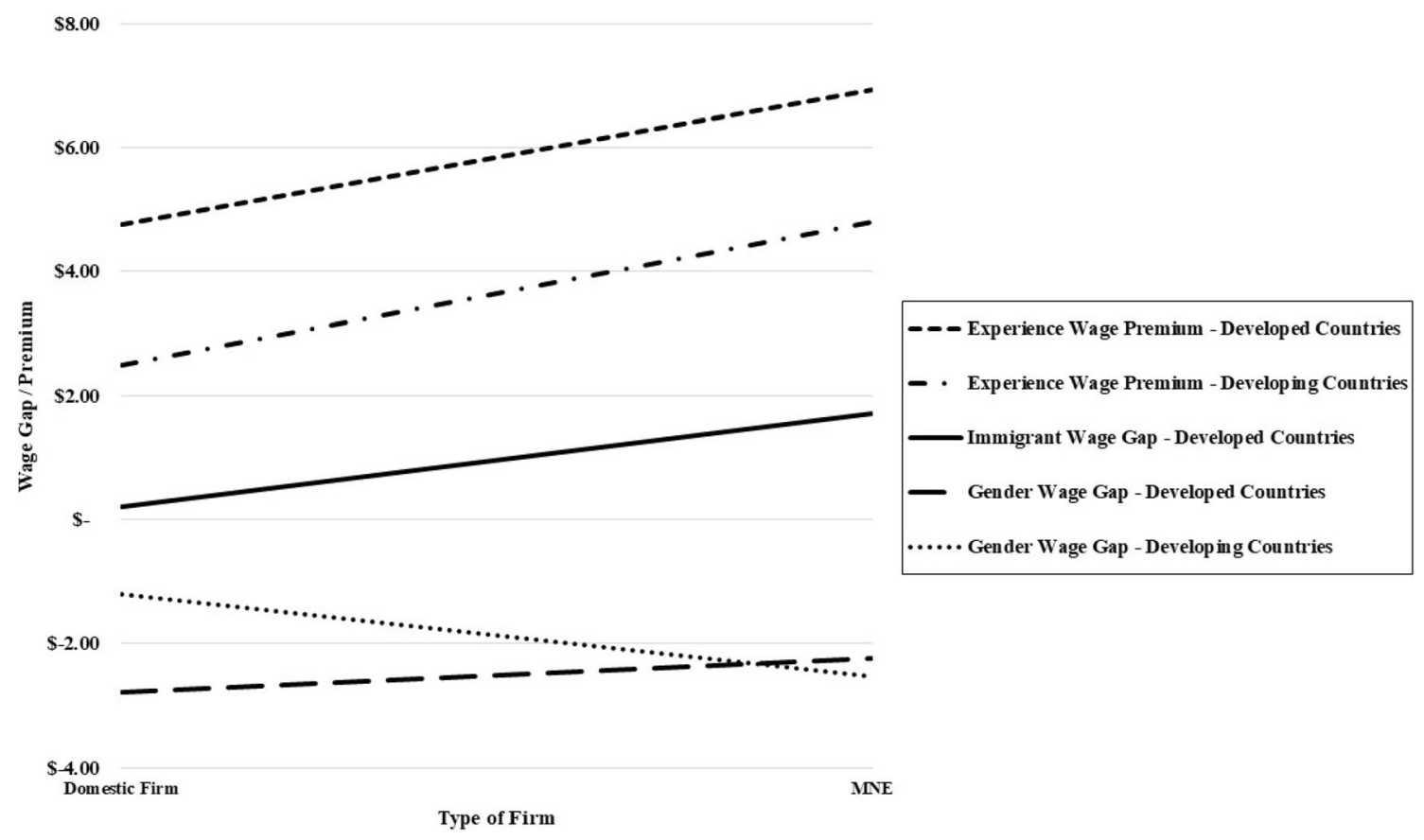

Figure 1 MNEs' distributional effects in developing versus developed countries. (1) To make the interpretation more informative, we transformed the marginal effects calculated - given that the dependent variable Wage corresponds to the natural logarithm of the employee's hourly wage at PPP - to be able to compute the average wage gap/premium in US dollars for each case as shown in the figure. (2) The immigrant wage gap for developing countries is not shown as the moderating effect of Immigrant on the relationship between MNE and Wage is not significant in developing countries (see model 5 in Table 4). (3) The gender wage gap is the difference between Wage for females and males. (4) The experience wage premium is the difference between Wage at -1 and +1 standard deviation of Experience. Given that the variable Experience is continuous, we also calculated the marginal effects at the minimum and maximum values. The results obtained corroborate the significance of the interaction - e.g., for developing countries the experience wage premium in domestic firms is $\$ 13.6$ while it goes up to $\$ 31.66$ in MNEs. (5) The immigrant wage gap is the difference between Wage for immigrants and non-immigrants.

Freedom, thus failing to validate Hypothesis $4 \mathrm{~b}$. This result suggests that MNEs' wages tend to be more sensitive to the security of property rights in a given host environment rather than to the specific flexibility of its labor regulations.

As for our previous set of findings, we plotted the results of our interaction tests in Figure 2, which shows the MNE wage premium as calculated based on the average marginal effects of MNE on the full range of Wage at -1 and +1 standard deviations of Property Rights. Figure 2 thus helps to visualize the economically significant impact of Property Rights on the underlying relationship between our main predictor MNE and Wage, and further corroborates our expectation that in the presence of stronger institutions supporting the protection of property rights, the MNE wage premium is significantly smaller.
Overall, the results we obtained when distinguishing between developed and developing countries as well as the ones resulting from our analysis on the moderating role of host-country's level of property rights protection emphasize the relevance of focusing on the specificities and heterogeneities of host-country locations. Our findings showing that MNEs' distributional effects in terms of gender, experience, and immigrant status all differ by level of institutional development corroborate the role of institutional development on MNEs' behavior. Moreover, the analysis reveals that the MNE wage premium is particularly sensitive to changes in property rights protection - as shown in Figure 2, the MNE wage premium goes from approximately $\$ 1.00$ to slightly over $\$ 3.50$ when property rights move from high to low. This further corroborates the importance of focusing on the safeguarding of property rights, especially in the context of 
Table 5 MNE wage premium and the influence of host-country institutions

\begin{tabular}{|c|c|c|c|c|c|c|}
\hline \multirow[t]{4}{*}{ Variables } & \multicolumn{3}{|c|}{ Model 1} & \multicolumn{3}{|c|}{ Model 2} \\
\hline & \multicolumn{3}{|c|}{ Property rights moderating effect } & \multicolumn{3}{|c|}{ Labor freedom moderating effect } \\
\hline & \multicolumn{3}{|c|}{ DV: Wage } & \multicolumn{3}{|c|}{ DV: Wage } \\
\hline & Coeff. & s.e. & $p$ value & Coeff. & s.e. & $p$ value \\
\hline \multicolumn{7}{|l|}{ Fixed effects } \\
\hline Supervisor & 0.00 & 0.00 & 0.00 & 0.00 & 0.00 & 0.00 \\
\hline Education & 0.29 & 0.01 & 0.00 & 0.29 & 0.01 & 0.00 \\
\hline Firm size & 0.06 & 0.00 & 0.00 & 0.06 & 0.00 & 0.00 \\
\hline Export intensity & 0.02 & 0.01 & 0.00 & 0.02 & 0.01 & 0.00 \\
\hline Import intensity & 0.01 & 0.01 & 0.40 & 0.01 & 0.01 & 0.41 \\
\hline Power distance & -0.02 & 0.01 & 0.00 & -0.02 & 0.01 & 0.00 \\
\hline Uncertainty avoidance & 0.01 & 0.01 & 0.06 & 0.01 & 0.00 & 0.06 \\
\hline Masculinity & 0.01 & 0.00 & 0.02 & 0.01 & 0.00 & 0.02 \\
\hline Religious diversity & -0.97 & 0.40 & 0.02 & -0.97 & 0.40 & 0.02 \\
\hline Language diversity & 0.41 & 0.25 & 0.09 & 0.41 & 0.25 & 0.09 \\
\hline Female & -0.17 & 0.01 & 0.00 & -0.17 & 0.01 & 0.00 \\
\hline Experience & 0.02 & 0.00 & 0.00 & 0.02 & 0.00 & 0.00 \\
\hline Property rights & 0.01 & 0.00 & 0.00 & 0.01 & 0.00 & 0.00 \\
\hline Labor freedom & 0.00 & 0.01 & 0.98 & -0.00 & 0.01 & 0.99 \\
\hline MNE & 0.58 & 0.12 & 0.00 & -0.03 & 0.35 & 0.94 \\
\hline MNExProperty rights & -0.01 & 0.00 & 0.00 & & & \\
\hline MNExLabor freedom & & & & 0.01 & 0.01 & 0.38 \\
\hline Constant & 0.61 & 0.61 & 0.32 & 0.63 & 0.61 & 0.30 \\
\hline \multicolumn{7}{|l|}{ Random effects } \\
\hline \multicolumn{7}{|l|}{ Industry level } \\
\hline$\sigma^{2} \mathrm{MNE}$ & 0.01 & 0.01 & 0.00 & 0.01 & 0.01 & 0.00 \\
\hline$\sigma^{2}$ Constant & 0.03 & 0.00 & 0.00 & 0.03 & 0.00 & 0.00 \\
\hline \multicolumn{7}{|l|}{ Country level } \\
\hline$\sigma^{2} \mathrm{MNE}$ & 0.03 & 0.01 & 0.00 & 0.04 & 0.02 & 0.00 \\
\hline$\sigma^{2}$ constant & 0.04 & 0.02 & 0.00 & 0.04 & 0.02 & 0.00 \\
\hline Number of observations & 40,258 & & & 40,258 & & \\
\hline Number of groups (industry) & 332 & & & 332 & & \\
\hline Number of groups (country) & 13 & & & 13 & & \\
\hline Wald $\chi^{2}$ & 6397.57 & & 0.00 & 6370.99 & & 0.00 \\
\hline $\operatorname{LR} \chi^{2}$ & 2580.71 & & 0.00 & 2674.65 & & 0.00 \\
\hline
\end{tabular}

developing countries that need to upgrade their institutional environments on this point (cf. Brandl, Darendeli, \& Mudambi, 2019).

\section{Results of the Post Hoc Analysis}

As a post hoc analysis, we examined the interplay between MNEs' distributional effects and the influence of host-country institutions. Thus, we estimated mixed effects models to test for three-way interactions - e.g., for the gender wage gap and the effect of Property Rights, we included the following interaction terms: MNExFemale, MNExProperty Rights, FemalexProperty Rights, and MNExFemalexProperty Rights - and then calculated the average marginal effects of MNE on Wage. This allowed us to compute the average gender wage gaps in domestic firms and MNEs at -1 and +1 standard deviations of Property Rights (thus corresponding to a high and low level of Property Rights, respectively). We repeated the same analysis for the experience wage premium and the immigrant wage gap and for each of the three did the same calculations for Labor Freedom. Table 6 shows the results obtained, with highlighted in bold the differences between domestic firms and MNEs that are statistically significant at the 0.05 level.

The findings show that while for domestic firms the gender wage gap oscillates between $-\$ 1.69$ and $-\$ 2.43$ across the different types of hostcountry institutions, we observe greater variation when looking at MNEs. Specifically, the gender wage gap is smallest $(-\$ 1.26)$ in MNEs based in 


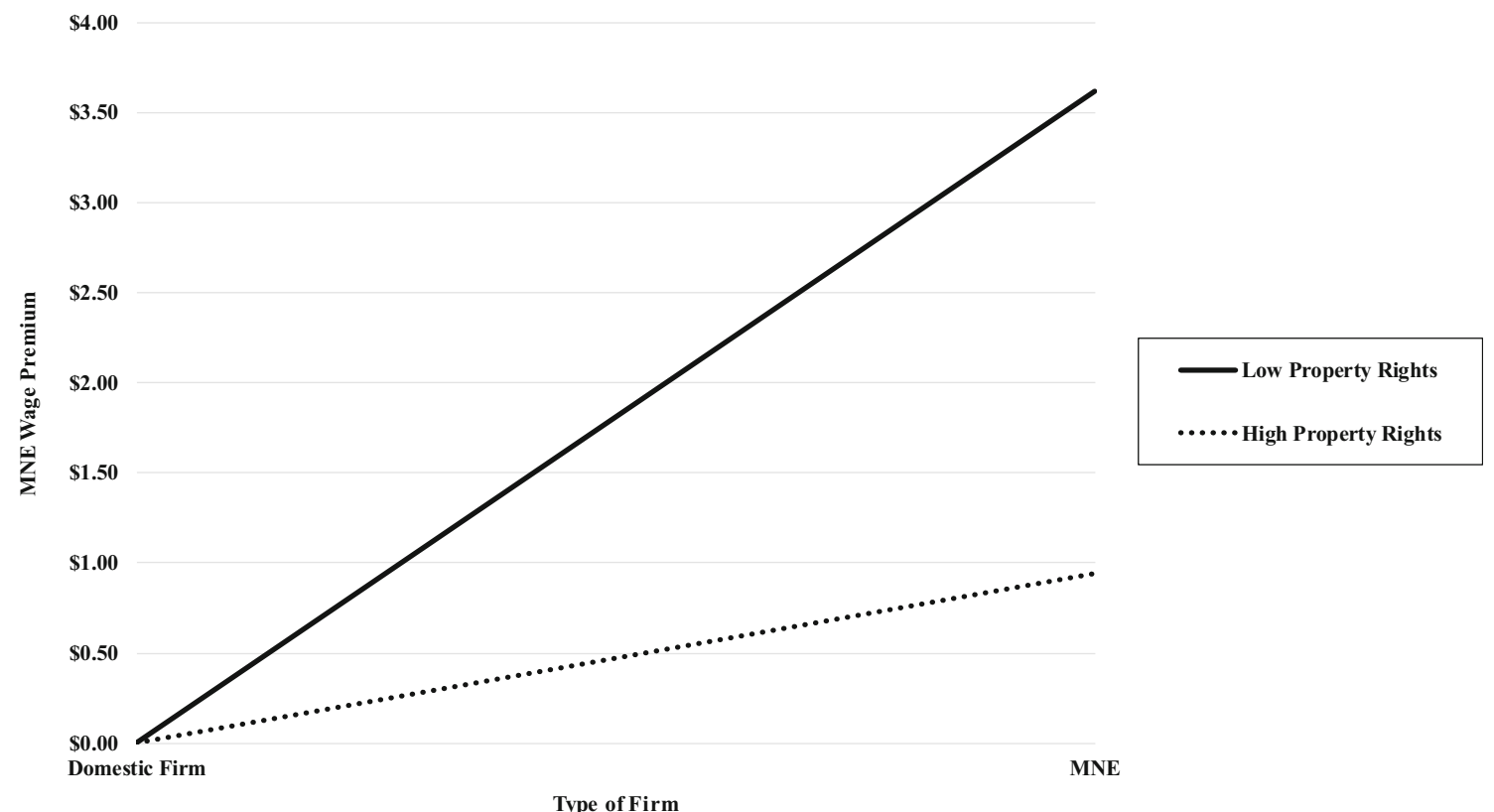

Figure 2 MNE wage premium and its interaction with host-country's level of property rights protection. (1) We transformed marginal effects as detailed in footnote 1, Figure 1, to make their interpretation more informative. (2) The moderating effect of Labor Freedom on the relationship between MNE and Wage is not significant (see model 2 in Table 5). Hence the figure is solely focused on the moderating effect of Property Rights. (3) We calculated the MNE wage premium based on the average marginal effects of MNE on the full range of Wage at -1 and +1 standard deviations of Property Rights (corresponding to a low and a high level of Property Rights, respectively). Given that the variable Property Rights is continuous, we also calculated the marginal effects at the minimum and maximum values. The results obtained corroborate the significance of the interaction as the MNE wage premium at the highest level of property rights protection is $\$ 1.07$, while it goes up to $\$ 3.95$ at the lowest level of property rights protection.

Table 6 MNEs' distributional effects and their interplay with host-country institutions ${ }^{1,2}$

\begin{tabular}{|c|c|c|}
\hline & Domestic firms & MNEs \\
\hline \multicolumn{3}{|c|}{ A: Gender wage gap } \\
\hline \multicolumn{3}{|c|}{ Host-country institutions } \\
\hline Low property rights & $-\$ 1.69(-19 \%)$ & $-\$ 2.88(-22 \%)$ \\
\hline High property rights & $-\$ 2.16(-14 \%)$ & $-\$ 1.93(-11 \%)$ \\
\hline Low labor freedom & $-\$ 1.77(-14 \%)$ & $-\$ 1.26(-9 \%)$ \\
\hline High labor freedom & $-\$ 2.43(-19 \%)$ & $-\$ 4.35(-24 \%)$ \\
\hline \multicolumn{3}{|c|}{ B: Experience wage premium } \\
\hline \multicolumn{3}{|c|}{ Host-country institutions } \\
\hline Low property rights & $\$ 3.09(47 \%)$ & $\$ 6.50(72 \%)$ \\
\hline High property rights & $\$ 4.70(37 \%)$ & $\$ 5.86(45 \%)$ \\
\hline Low labor freedom & $\$ 3.33(33 \%)$ & $\$ 4.31(36 \%)$ \\
\hline High labor freedom & $\$ 5.28(58 \%)$ & $\$ 9.86(82 \%)$ \\
\hline \multicolumn{3}{|c|}{ C: Immigrant wage gap } \\
\hline \multicolumn{3}{|c|}{ Host-country institutions } \\
\hline Low property rights & $-\$ 0.55(-7 \%)$ & $-\$ 2.27(-19 \%)$ \\
\hline High property rights & $\$ 0.39(2 \%)$ & $\$ 1.78(11 \%)$ \\
\hline Low labor freedom & $\$ 0.01(0 \%)$ & $\$ 1.31(8 \%)$ \\
\hline High labor freedom & $-\$ 0.16(-1 \%)$ & $-\$ 0.97(-6 \%)$ \\
\hline
\end{tabular}

\footnotetext{
1 In bold are the average marginal effects for which the three-way interaction is significant at the 0.05 level.

2 To obtain the margins reported in the above tables we ran a total of six mixed effects models to test for three-way interactions. In each model, we included all control and explanatory variables considered in our main analysis together with the following interaction terms (e.g., for gender wage gap and Property Rights): MNExFemale, MNExProperty Rights, FemalexProperty Rights, and MNExFemalexProperty Rights. This allowed us to compute the average gender wage gaps in domestic firms and MNEs at -1 and +1 standard deviations of Property Rights (thus corresponding to a high and low level of Property Rights, respectively). The complete output of each model estimated for this post hoc analysis is available upon request.
} 
countries characterized by a high rigidity of the labor market, while it is largest $(-\$ 4.35)$ in country contexts in which labor flexibility is high. These findings suggest that MNEs are more sensitive (and not always in a virtuous way) to the local institutional environment when it comes to reducing wage differences between males and females. Looking at the results for the experience wage premium, we find that MNEs pay higher wages than domestic firms independent from the host-country institutional environments. Having said that, the greatest experience wage premium that we observed is again in correspondence to a high flexibility of the labor market (\$9.86). This is the likely consequence of the fact that in such environments MNEs have more room for maneuver in the hiring process and performance appraisal of their employees, and they are not bound to strong union-driven collective bargaining agreements for existing employees. Thus, they have greater opportunities to better remunerate their more experienced employees. Moving to MNEs' distributional effects concerning the immigrant status of their employees, the findings reported in Table $6 \mathrm{c}$ show that the immigrant wage gap turns into a premium under certain hostcountry institutional conditions, with the highest premium (\$1.78) observed in MNEs based in countries with high property rights protection.

In Table 7 we evaluated the presence of region and industry effects and thus analyzed MNEs' distributional impacts relative to employees' gender, experience, and immigrant status distinguishing between three key regions represented in our sample (i.e., Asia, Latin America, and Europe). We then repeated the same analysis for the three main industrial groupings included in our empirical setting. The results provided in Table 7 show that the gender wage gap is largest in MNEs in Latin America (where traditional gender roles prescribe women to fulfill a private, family role as discussed by e.g., Hermans et al., 2017) while it is lowest in Asia (although the three-way interaction is not significant). As for the industry groupings analyzed, the largest gap is again observed in MNEs, specifically the ones active in agriculture, manufacturing, and construction.

In relation to the experience wage premium, we observe the highest premium for MNEs in Asia and the lowest one for domestic firms in Europe. Considering the industry-level analysis, our findings show the highest experience premium in the trade, transportation, and hospitality grouping. Finally, looking at the immigrant wage gap, our results show that the immigrant wage premium is largest (\$1.20) in MNEs in Europe (compared to only 10 cents in domestic firms). This difference suggests the likely presence of an "expat" effect and/or a premium for cultural transcendence when it comes to the higher wages paid by MNEs in this region. As for differences across industries, our findings suggest that MNEs are responsible for both the largest immigrant wage gap $(-\$ 1.09$ in the trade, transport, and hospitality grouping) and premium $(\$ 2.21$, in the commercial services category), although none of the three-way interactions results is significant in our empirical setting. Overall, the post hoc analysis conducted here furthers our understanding of MNEs' distributional effects in the host countries in which they operate, containing important (broader) implications for both IB research and practice that will be discussed in greater detail in the final section of our paper.

\section{Robustness Checks}

Except for a few exceptions - the moderating HFI variables - all dependent, independent, and moderating variables are constructed from answers to the WageIndicator survey, and a common method bias might therefore be present. The risk of this bias is low, however, as the variables are constructed from very specific and unambiguous questions on personal and firm characteristics such as gender and firm size. Moreover, the surveys were conducted anonymously, and respondents cannot be linked to their employer, reducing the potential of an evaluation apprehension bias (Podsakoff, MacKenzie, Lee, \& Podsakoff, 2003). Having said that, we performed the Harman's single-factor test to test for common method bias (Podsakoff et al., 2003), i.e., we ran exploratory factor analysis to determine the number of factors that are necessary to account for the variance in the variables. We included all variables constructed from WageIndicator data and confirmed that these variables did not load onto a single factor (three with an eigenvalue above 1). Thus, we do not expect issues of common method bias to affect our results.

To ensure the empirical validity of our results, we performed additional robustness checks reported in Table 8. First, we repeated our analysis including the firm level and thus adopting a hierarchical model in which firms are nested in industries and industries are nested in countries. As mentioned in the previous section, to ensure anonymity, employees did not specify the firm for which they were working at the time of completion of the survey. To 
Table 7 MNE wage premium by region and industry grouping ${ }^{1,2,3,4,5,6}$

\begin{tabular}{|c|c|c|}
\hline & Domestic firms & MNEs \\
\hline \multicolumn{3}{|l|}{ A: Gender wage gap } \\
\hline \multicolumn{3}{|l|}{ Regions } \\
\hline Asia & $-\$ 0.23(-4 \%)$ & $-\$ 1.54(-15 \%)$ \\
\hline Latin America & $-\$ 1.72(-22 \%)$ & $-\$ 3.72(-33 \%)$ \\
\hline Europe & $-\$ 2.43(-16 \%)$ & $-\$ 1.49(-8 \%)$ \\
\hline \multicolumn{3}{|l|}{ Industry groupings } \\
\hline Agric./manufacturing/constr. & $-\$ 1.64(-15 \%)$ & $-\$ 3.04(-21 \%)$ \\
\hline Trade/transport/hospitality & $-\$ 1.42(-15 \%)$ & $-\$ 1.52(-12 \%)$ \\
\hline Commercial services & $-\$ 2.32(-18 \%)$ & $-\$ 1.92(-12 \%)$ \\
\hline \multicolumn{3}{|c|}{ B: Experience wage premium } \\
\hline \multicolumn{3}{|l|}{ Regions } \\
\hline Asia & $\$ 5.09(115 \%)$ & $\$ 12.23(194 \%)$ \\
\hline Latin America & $\$ 3.21(55 \%)$ & $\$ 5.19(67 \%)$ \\
\hline Europe & $\$ 4.09(33 \%)$ & $\$ 6.12(41 \%)$ \\
\hline \multicolumn{3}{|l|}{ Industry groupings } \\
\hline Agric./manufacturing/constr. & $\$ 4.12(43 \%)$ & $\$ 4.83(41 \%)$ \\
\hline Trade/transport/hospitality & $\$ 2.62(34 \%)$ & $\$ 5.31(63 \%)$ \\
\hline Commercial services & $\$ 4.29(44 \%)$ & $\$ 7.09(59 \%)$ \\
\hline \multicolumn{3}{|l|}{ C: Immigrant wage gap } \\
\hline \multicolumn{3}{|l|}{ Regions } \\
\hline Asia & $-\$ 0.57(-18 \%)$ & $\$ 0.68(15 \%)$ \\
\hline Latin America & $-\$ 0.21(-3 \%)$ & $-\$ 0.83(-8 \%)$ \\
\hline Europe & $\$ 0.10(1 \%)$ & $\$ 1.20(7 \%)$ \\
\hline \multicolumn{3}{|l|}{ Industry groupings } \\
\hline Agric./manufacturing/constr. & $-\$ 0.26(-2 \%)$ & $\$ 0.24(2 \%)$ \\
\hline Trade/transport/hospitality & $-\$ 0.16(-2 \%)$ & $-\$ 1.09(-9 \%)$ \\
\hline Commercial services & $\$ 0.71(6 \%)$ & $\$ 2.21(14 \%)$ \\
\hline
\end{tabular}

\footnotetext{
${ }^{1}$ In bold are the average marginal effects for which the three-way interaction is significant at the 0.05 level.

2 To obtain the margins reported in the above tables, we ran a total of 18 mixed effects models. Specifically, we repeated the estimation as per models 2,3 , and 4 from Table 3 each six times in correspondence to the subsamples obtained according to the regions and industry groupings considered. In the post hoc analysis performed here, we use industry dummies rather than an industry level to allow for enough variation at the country level in view of the relatively lower size of (sub)samples considered. The complete output of each model estimated for this post hoc analysis is available upon request. 3 To obtain the percentages we proceeded as follows. For the gender wage gap, we calculated the percentage difference between the average wage of females and males, for the experience wage premium the percentage difference between the average wage at -1 and +1 standard deviations of Experience, and for the immigrant wage gap the percentage difference between the average wage of immigrants and non-immigrants.

${ }^{4}$ Africa is excluded because our sample contains just one African country.

5 The public sector is excluded because of its low proportion of MNE employees $(<0.01 \%)$.

${ }^{6}$ As mentioned in the main text, the analysis that includes the Immigrant variable was done on a smaller sample. Thus, the sub-sample analysis reported in Table $7 c$ is in turn also done on (sub)samples that are smaller than the ones used for the analyses reported in Tables $7 a$ and $b$.
}

calculate the firm-level ICC, we combined variables on firm characteristics (firm size, industry, country, typology - MNE versus domestic firm - and private/public sector) and thus identified groups of respondents that could potentially work for the same firm. Based on this grouping, despite the fact that the firm-level ICC remains relatively low (0.11), we repeated our main model estimation including the firm level to determine whether this may have an influence on our findings. The results reported in model 1 in Table 8 show no differences vis-à-vis the original model: the MNE wage premium is $32.3 \%\left(e^{0.28}-1\right)$ when including the firm level, that is equivalent to the one obtained in our main analysis (Model 1 in Table 3). While it is important to emphasize that in our sample the average group size at the firm level is too small to produce accurate estimates (Hox, 2010), the results obtained here lend additional support to our main conclusions.

Secondly, we performed additional analyses to account for the potential endogeneity of our main predictor MNE. This is because firms may self-select into the MNE (versus domestic) category due to unobserved firm characteristics and this may bias the results of our estimation. To take into account such potential selection bias in our analysis, we followed common procedure (Bascle, 2008) and used Heckman's (1979) two-stage estimation procedure. In the first stage, we estimated the selection 


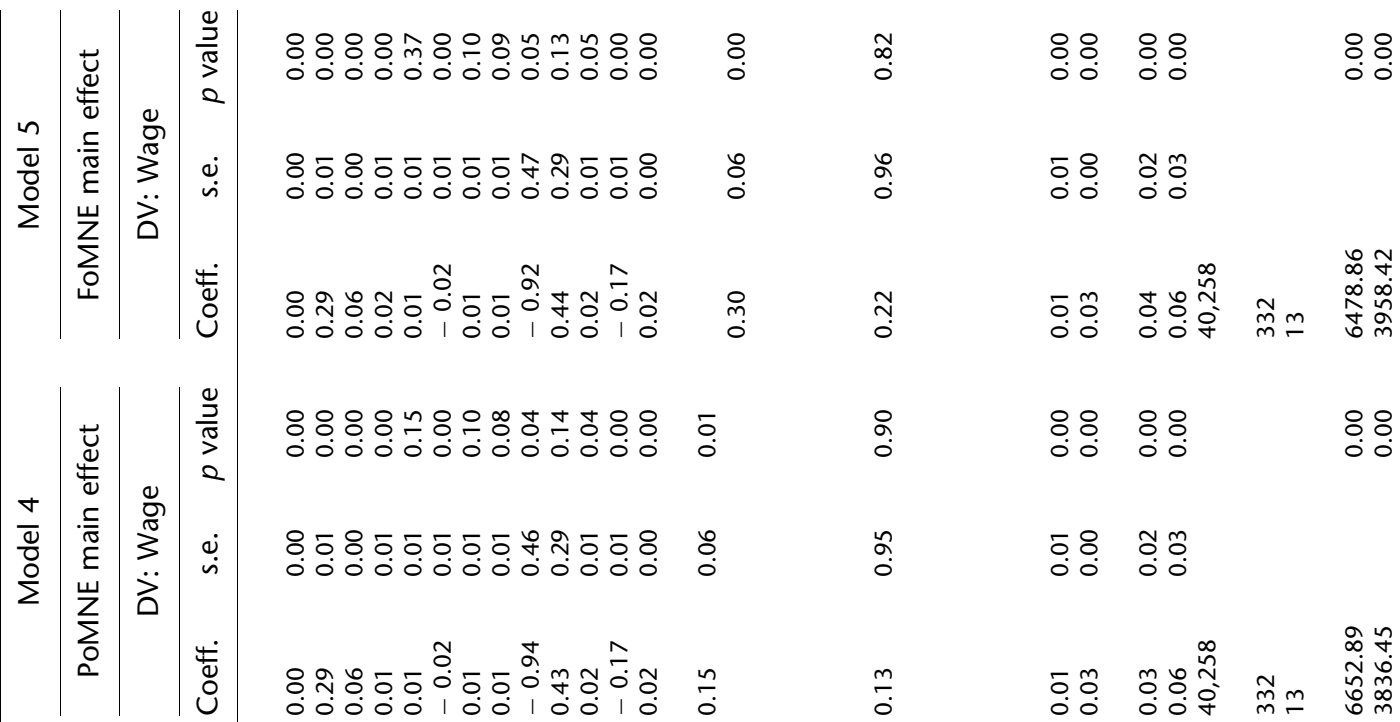

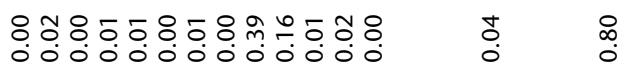

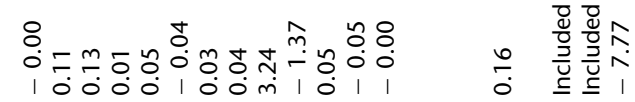

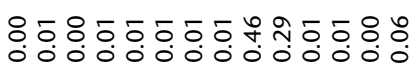

ถ̊․

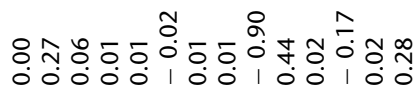

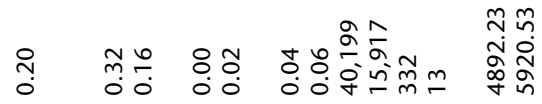

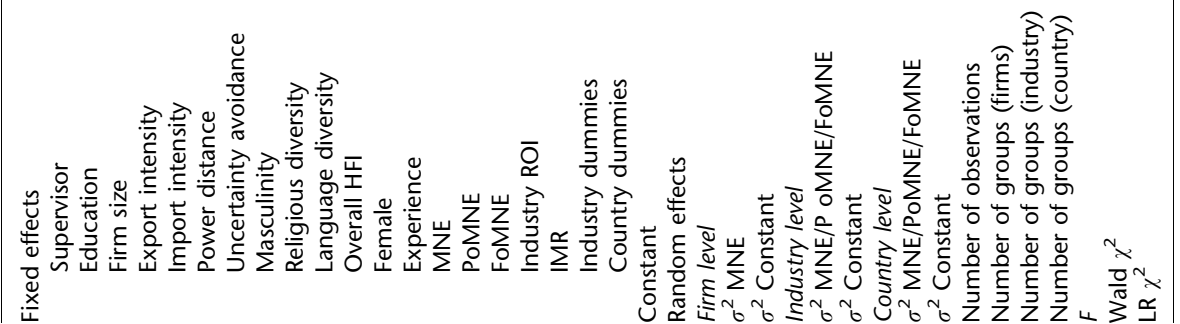


equation using a probit model in which the limited (dummy) dependent variable is the propensity to be an MNE versus a domestic firm - that is precisely our MNE variable - and used the set of explanatory variables included in our main analysis (i.e., Model 1 in Table 3) as our independent variables. In this first stage, we also included our main exclusion variable corresponding to the return of investment (ROI) of the industry in which the focal employee works (Industry ROI). We expected this variable to be related to MNE but not to Wage, thus satisfying the exclusion restriction of Heckman's (1979) twostage estimation procedure. Our expectation builds on previous research showing that industry-level profitability influences firms' decision to make foreign acquisitions (Asiedu, 2002; Demirbag, $\mathrm{Ng}$, $\&$ Tatoglu, 2007) and thus internationalize (Ruigrok \& Wagner, 2003), but not the wages paid to their employees (Abowd, Kramarz, \& Roux, 2006). This is confirmed in our empirical setting, as Industry ROI significantly correlates with MNE $(0.03, p$ value $=0.00)$ but not with Wage (0.00, $p$ value $=0.25)$. The first stage allowed us to compute the inverse Mills ratio (IMR), which represented our selection parameter that we included in the second stage to account for potential selection bias and thus obtain consistent and unbiased coefficients. In the second stage, we ran an ordinary least-squares model with robust standard errors using the same dependent and explanatory variables as included in our main model specification and adding the inverse Mills ratio obtained from the selection equation estimated in the first stage. Models 2 and 3 in Table 8 correspond to our firstand second-stage models, respectively. The secondstage results are entirely aligned with those obtained without correcting for the potential endogeneity of MNE. Additionally, the coefficient associated with the inverse Mills ratio is not significant. Thus, the findings of these additional analyses provide strong evidence that our findings do not suffer from potential selection bias.

Finally, because of the proven relationship between entry mode decisions and the level of firm-specific knowledge possessed by internationalizing firms (Agarwal \& Ramaswami, 1992; Ahsan \& Musteen, 2011; Brouthers, 2013), we also tested whether the degree of foreign ownership in MNEs may have an effect on the MNE wage premium observed in our empirical setting. While it is reasonable to expect a higher MNE wage premium in the case of full (versus partial) ownership because of its association with a higher level of resource commitment and firm-specific knowledge (Ahsan \& Musteen, 2011; Brouthers, 2013; Filatotchev, Strange, Piesse, \& Lien, 2007) that increase the risk of knowledge spillovers through employee turnover (and thus the related need for MNEs to pay even higher wages to retain their employees), for both cases we should anyway observe a wage premium when comparing MNEs versus domestic firms. In order to perform this test, we estimated the effect on Wage of partially (PoMNE) and fully foreign owned MNEs (FoMNE) in Models 4 and 5 (in Table 8), respectively. Following our expectations, the MNE wage premium is positive and significant in both models, being higher in the case of fully foreign-owned MNEs. This further corroborates the presence of an MNE wage premium when considering the different types of entry modes decisions that can be identified in our empirical setting.

\section{DISCUSSION AND CONCLUSIONS}

This paper enters the broader debate on the positive and/or negative impacts of MNEs in host countries, which has recently received renewed attention, particularly in perspective agenda-setting papers in IB journals that highlight the need for a better understanding of the nuanced relationships between FDI and inequality (Doh, 2019; Giuliani, 2019; Narula, 2019). Most pronounced is the title of Giuliani's piece exploring "why multinationals may be causing more inequality than we think," but as her paper focused on human rights, we more directly engage with wage inequality, underlined as a crucial topic by Doh (2019). Interestingly, while economics research has provided generic evidence for the existence of an MNE wage premium in specific countries, and there are separate studies showing that females are often paid less than males, we lack a proper, more comprehensive insight into distributional effects including MNEs and domestic firms across a range of countries and industries, and accounting for key host-country institutions. Using unique micro-level data from over 40,000 employees in 13 countries and working in 32 different industries, our 'unraveling' paper, while confirming that it does pay to work for a multinational to start with, most importantly investigates for whom, how and in which contexts the MNE wage premium actually materializes.

\section{Implications for Research and Practice}

Our study provides important empirical insights into, and contributes to, the debate on the impact 
of MNEs in host countries. Our results unveil MNEs' distributional effects with marked differences that largely depend on the host-country context, and that are positive for experienced and international employees in developed countries but negative for females working in developing countries and anyway in contexts characterized by low labor regulation. Our findings thus suggest the need to reassess statements about the generic positive impact of MNEs in host countries, particularly in developing countries. Furthermore, solely pointing out the potential of economic growth through productivity spillovers appears insufficient to demonstrate the positive impact of MNEs' presence in host countries, as the wage premium that MNEs are paying could in part be motivated by the desire to actually prevent horizontal productivity spillovers. While Oetzel and Doh (2009) are critical of the IB focus on the benefits of MNEs' spillovers for host countries because this effect is unintentional, we go one step further and argue that horizontal spillovers are undesirable from an MNE's perspective because they erode their ability to exploit their productivity advantages and thereby their competitiveness, and MNEs might intentionally try to prevent them.

Moreover, the IB focus on spillovers as the source of positive development outcomes for host countries may have led to a certain confirmation bias (Narula \& Driffield, 2012). Despite the fact that early IB research already emphasized that MNEs' presence may not have only positive effects on development, or even a net positive outcome overall (Dunning, 1958, 1981, 1994; Hymer, 1975; Lall, 1980), the subsequent stream of IB studies investigating possibly negative outcomes of MNEs' activities in host countries is by no means as large as the one focused on the potential benefits of FDI. As a result, we are only beginning to untangle the nature and dimensions of MNEs' potential negative effects in the host environment (Narula \& Dunning, 2010). Despite the potential of vertical spillovers, we think that more convincing and compelling arguments are needed for MNEs to be viewed as 'assets' by those who do not benefit from MNEs' wage premia. Importantly, however, our post hoc analysis indicates that MNEs' distributional effects vary as a result of differences in the host-country institutional environment as well as across regions and industries. Thus, more finegrained IB studies focused on the role of host country context in shaping MNEs' effects are much needed to further our understanding of how, and under which conditions, MNEs contribute to the development of the regions in which they invest and operate.

Our results suggest that a further careful and indepth evaluation of the consequences of MNEs' activities across borders seem to be in order; gender inequality is a case in point. On the one hand, our study shows a smaller gender wage gap in MNEs compared with domestic firms in developed countries. As we hypothesized, this is a likely consequence of MNEs' highly formalized international HRM systems and, especially, greater attention to their role and reputation as good "global citizens". On the other hand, in developing countries MNEs are found to be associated with an even larger gender wage gap than domestic firms. One possible explanation may be that, with the dominant presence of developedcountry investors and board members, global HRM systems primarily adopted by MNEs have converged towards developed-country standards (Ferner et al., 2001; Festing, 2012; Pudelko \& Harzing, 2007) which consider female life patterns in developed countries as broadly applicable across regions, for instance in relation to pregnancy leaves and child care permissions. However, on other aspects, which are less related to formalized rights and more to (culturally based) perceptions of the role of women in the family and in society, substantial differences exist across countries. Examples might be diverging expectations on the role of women in taking care of elderly parents, or limitations in traveling or moving internationally, a particularly relevant aspect when working for an MNE (Hewlett \& Rashid, 2010). Thus, while in a developed-country setting an increasing standardization of HRM systems in MNEs seem to have contributed to reducing the gap between males and females, our findings suggest that such convergence has worked out differently or not at all in other contexts.

In line with recent work by Brandl et al. (2019), our findings corroborate the centrality of property rights protection in shaping MNEs' behavior, especially in developing countries characterized by a relatively poorer safeguard of such rights. While these authors show that, in developing countries, (developed-country) MNEs can play an active role in addressing institutional voids such as poor intellectual property rights protection, other studies have suggested that the homogenization of 
intellectual property protection standards can harm local (developing-country) firms that often lack the capacity to absorb knowledge resulting from MNE spillovers and therefore rely on imitation and reverse engineering (Li, 2008; Samuelson \& Scotchmer, 2002), a process prevented by such standards. Thus, although our results show that the MNE wage premium is highly sensitive to property rights protection, corroborating its role in influencing MNEs' behavior in the host-country environment, it is important to note that the fact that the MNE wage premium is considerably higher in (developing) countries characterized by low property rights protection does not necessarily mean that these higher wages paid by MNEs contribute to local institutional development in the same way, as the benefits of enhanced intellectual property protection do not always materialize for local actors in developing economies as they do in developed ones (Criscuolo \& Narula, 2008). Overall, our findings reaffirm the importance for further careful assessment and evaluation of the difference in outcomes in developing versus developed countries that is especially pronounced because of the high levels of complexity, market segmentation and heterogeneity, and institutional unpredictability characterizing developing countries (Luo, Zhang, $\& \mathrm{Bu}, 2019)$.

We see important implications for MNE strategy as our results should be interpreted in a wider context on the role of multinationals in host countries. In the vast majority of countries, income inequality has risen, although at very different speeds depending on country-specific institutions, a phenomenon noted in the 2018 World Inequality Report (Alvaredo et al., 2017). MNEs seem to have a direct effect on income inequality if they pay their employees a wage premium above the local average wages. While obviously beneficial for employees receiving the wage premium, it is not for the hostcountry society as a whole. Moreover, as discussed earlier, our results suggest the MNE wage premium is not distributed equally among employees when considering their gender and immigrant status. Income inequality is associated with a wide variety of societal problems such as increased crime rates, substance abuse, and mental health problems (Nolan et al., 2014; Wilkinson \& Pickett, 2009). This comes on top of creating "economic anxiety, discontent, loss of legitimacy, and fairness concerns" (Rodrik, 2018, p. 13) feeding into populism and anti-globalization sentiments in general, and anti-MNE sentiments in particular (cf. Kobrin, 2017). As MNEs are an even easier political and societal target than globalization, trade agreements or job-'saving' technologies (Eden \& Lenway, 2001), it is important for MNEs to (re)assess their impact in a precise manner, also considering - as our study implies - the different possible components of the wage gap and the particular hostcountry context. Thus, assessments should go beyond just highlighting mere numbers of jobs created, wages or taxes paid, or even community projects funded, as important and substantial as they may be. A recent in-depth investigation of multinationals and their stakeholders in a developing country showed that perceptions matter here as well, meaning that choosing the right ways of communicating and collaborating in communities is crucial (Kolk \& Lenfant, 2018).

\section{Limitations and Further Areas for Investigation}

Despite the contributions, it should be noted that this paper is only a first step in an area of research that we argue to be in need of much further development. In the Appendix, we discuss the limitations of the WageIndicator dataset used for our study as well as its unique characteristics that make it, to date, the most suitable source of crosscountry data on wages that allows for an extensive comparison of MNEs versus domestic firms across countries. While the continuous update and extension of this dataset might enable further investigation to help shed further light on this crucial aspect of MNEs' activities in host countries, we also hope for new data sources to become available in the (near) future so as to really give researchers the opportunity to deepen and improve insights. One interesting avenue for research could, for instance, be additional micro-level assessment of the relationship between MNEs and wages, considering the role of other firm-level factors that could not be captured in our work as the data did not contain firm-specific characteristics beyond multinational activity, size, and ownership. Furthermore, it would be worthwhile to add countries to those that we could include in this study, especially least-developed countries, and given the results of our post hoc analysis, which showed some specific effects per region and industry for some of the wage premium components, in-depth (qualitative) research seems a valuable direction as well. 
Future studies could also benefit from the use of longitudinal data to include time effects and identify differences between within- and between-group effects on the MNE wage premium. Despite the challenges of obtaining a panel dataset that would allow for the assessment of these specific MNE effects, it can help to better understand the influence of country- and industry-level policies designed to attract MNEs seeking low wages at one end of the spectrum, or highly productive talented employees on the other end, both of which are expected to have an influence on the average wages paid by MNEs. We also want to point at a further limitation of our empirical analysis which is that the place of birth remains a relatively rough proxy for the 'immigration' effect - or 'outsidership' effect as contextualized by Johanson and Vahlne (2009) - that we test in our study. While additional information on employees' background would have been helpful to specify the nature of their immigrant status, retrieving such data was not possible for our large-scale sample. Finergrained data on employees' personal and/or professional trajectories (as e.g., Zikic, Bonache, and Cerdin (2010) did in their qualitative work) would be very useful to include in follow-up research on how differences in the 'immigrant' status may have an effect on the relationships examined in the current study. Finally, our data does not allow us to untangle the potential moderating effect of MNEs' homecountry institutional development (Pinkse \& Kolk, 2012) in this context, which we believe would also represent an interesting direction for further investigation. Hence, our study, which unraveled the MNE wage premium, and provided insight into MNEs' distributional effects and the role of the host-country institutional environment on such effects, additionally offers fruitful avenues for future research.

\section{ACKNOWLEDGEMENTS}

The authors are grateful to the editor and the three reviewers for their constructive comments, and to the Wagelndicator Foundation for the data of its websurvey on work and wages. The first author's research appointment was supported by a grant from the Netherlands Organisation for Scientific Research (No. 023.005.034).

\section{NOTES}

${ }^{1}$ An employee's wage is the pay(s) received for each hour of work, while salary is the pay over a fixed period of time (e.g., a month) irrespective of the number of working hours in that period. Stated otherwise, compensation covers all financial benefits an employer provides, thus including not only wages but also for instance bonuses, profit sharing, and health insurance (Borjas \& Van Ours, 2000).

${ }^{2}$ In our theorizing, empirical analyses, and subsequent discussion and conclusions, we always mean purely domestic firms even if the word 'purely' is not added to the phrase 'domestic firm' in the text.

${ }^{3}$ In the final section, we further discuss the empirical limitation associated with the use of place of birth as a proxy for an "immigration" or "outsidership" effect according to social identity theory.

${ }^{4}$ As stipulated by the WageIndicator Foundation, we refer to the dataset as Tijdens and Osse (2018). WageIndicator continuous web-survey on work and wages. Dataset 2013-2014.

${ }^{5}$ See Young et al. (2018) for an extensive discussion on the benefits of using HFI to assess the level of development of a given country and for a detailed description of how the index is constructed.

${ }^{6}$ The World Bank divides countries into four categories (low-, lower middle-, upper middle- and high-income) based on their annual gross national income per capita. We used the 2013 classification to split countries in our sample, distinguishing between developing (i.e., World Bank lower middle- and upper middle-income categories) and developed (i.e., World Bank high-income category). This is because there are no low-income countries included in our sample. The World Bank's classification based the GNI per capita is considered to be accurate and thus widely used for both operational and analytical purposes. For more information about this categorization, see https:// datahelpdesk.worldbank.org/knowledgebase/ articles/906519.

${ }^{7}$ See also Tijdens, Van Zijl, Hughie-Williams, Van Klaveren, and Steinmetz (2010), and www. wageindicator.org. 


\section{REFERENCES}

Abowd, J. M., Kramarz, F., \& Roux, S. 2006. Wages, mobility and firm performance: Advantages and insights from using matched worker-firm data. The Economic Journal, 116(512): F245-F285.

Abraham, M. 2017. Pay formalization revisited: Considering the effects of manager gender and discretion on closing the gender wage gap. Academy of Management Journal, 60(1): 29-54.

Acemoglu, D., \& Johnson, S. 2005. Unbundling institutions. Journal of Political Economy, 113(5): 949-995.

Achcaoucaou, F., Miravitlles, P., \& León-Darder, F. 2014. Knowledge sharing and subsidiary R\&D mandate development: A matter of dual embeddedness. International Business Review, 23(1): 76-90.

Agarwal, S., \& Ramaswami, S. N. 1992. Choice of foreign market entry mode: Impact of ownership, location and internalization factors. Journal of International Business Studies, 23(1): 1-27.

Aguilera, R. V., Judge, W. Q., \& Terjesen, S. A. 2018. Corporate governance deviance. Academy of Management Review, 43(1): 87-109.

Ahsan, M., \& Musteen, M. 2011. Multinational enterprises' entry mode strategies and uncertainty: A review and extension. International Journal of Management Reviews, 13(4): 376-392.

Aitken, B., Harrison, A., \& Lipsey, R. E. 1996. Wages and foreign ownership: A comparative study of Mexico, Venezuela, and the United States. Journal of International Economics, 40(3-4): 345-371.

Akresh, I. R. 2008. Occupational trajectories of legal US immigrants: Downgrading and recovery. Population and Development Review, 34(3): 435-456.

Alimov, A. 2015. Labor market regulations and cross-border mergers and acquisitions. Journal of International Business Studies, 46(8): 984-1009.

Almeida, R. 2007. The labor market effects of foreign owned firms. Journal of International Economics, 72(1): 75-96.

Altomonte, C., \& Pennings, E. 2009. Domestic plant productivity and incremental spillovers from foreign direct investment. Journal of International Business Studies, 40(7): 1131-1148.

Alvaredo, F., Chancel, L., Piketty, T., Saez, E., \& Zucman, G. 2017. World inequality report 2018. Paris: World Inequality Lab.

Anderson, E. 2005. Openness and inequality in developing countries: A review of theory and recent evidence. World Development, 33(7): 1045-1063.

Andersson, U., Cuervo-Cazurra, A., \& Nielsen, B. B. 2014). Explaining interaction effects within and across levels of analysis. Journal of International Business Studies, 45(9): 1063-1071.

Artuc, E., Chaudhuri, S., \& McLaren, J. 2014. Some simple analytics of trade and labor mobility. Washington: World Bank Policy Research Working Paper No. 7089.

Artz, B., Goodall, A. H., \& Oswald, A. J. 2018. Do women ask? Industrial Relations: A Journal of Economy and Society, 57(4): 611-636.

Asiedu, E. 2002. On the determinants of foreign direct investment to developing countries: Is Africa different? World Development, 30(1): 107-119.

Bapuji, H., Husted, B. W., Lu, J., \& Mir, R. 2018. Value creation, appropriation, and distribution: How firms contribute to societal economic inequality. Business and Society, 57(6): 983-1009.

Barrows, T. S. 2017. What do unions do? A twenty-year perspective. New York: Routledge.

Bascle, G. 2008. Controlling for endogeneity with instrumental variables in strategic management research. Strategic Organization, 6(3): 285-327.

Batjargal, B. 2007. Network triads: Transitivity, referral and venture capital decisions in China and Russia. Journal of International Business Studies, 38(6): 998-1012.

Ben Hamida, L. 2013. Are there regional spillovers from FDI in the Swiss manufacturing industry? International Business Review, 22(4): 754-769.
Ben Hamida, L., \& Gugler, P. 2009. Are there demonstrationrelated spillovers from FDI? Evidence from Switzerland. International Business Review, 18(5): 494-508.

Berry, H. 2017. Managing valuable knowledge in weak IP protection countries. Journal of International Business Studies, 48(7): 787-807.

Bettis, R. A., Ethiraj, S., Gambardella, A., Helfat, C., \& Mitchell, W. 2016. Creating repeatable cumulative knowledge in strategic management. Strategic Management Journal, 37(2): 257-261.

Beugelsdijk, S., Kostova, T., \& Roth, K. 2017. An overview of Hofstede-inspired country-level culture research in international business since 2006. Journal of International Business Studies, 48(1): 30-47.

Beugelsdijk, S., Maseland, R., \& Van Hoorn, A. 2015. Are scores on Hofstede's dimensions of national culture stable over time? A Cohort Analysis. Global Strategy Journal, 5(3): 223-240.

Björkman, I., Fey, C. F., \& Park, H. J. 2007. Institutional theory and MNC subsidiary HRM practices: Evidence from a threecountry study. Journal of International Business Studies, 38(3): 430-446.

Blalock, G., \& Simon, D. H. 2009. Do all firms benefit equally from downstream FDI? The moderating effect of local suppliers' capabilities on productivity gains. Journal of International Business Studies, 40(7): 1095-1112.

Blau, F. D., \& Kahn, L. M. 2017. The gender wage gap: Extent, trends, and explanations. Journal of Economic Literature, 55(3): 789-865.

Blomström, M., \& Kokko, A. 2002. FDI and human capital. Paris: OECD Working Paper No. 195.

Borjas, G. J., \& Van Ours, J. C. 2000. Labor economics. Boston: McGraw-Hill.

Bossard, A. B., \& Peterson, R. B. 2005. The repatriate experience as seen by American expatriates. Journal of World Business, 40(1): 9-28.

Boulton, T. J., Smart, S. B., \& Zutter, C. J. 2010. IPO underpricing and international corporate governance. Journal of International Business Studies, 41(2): 206-222.

Bourguignon, F. 2015. The globalization of inequality. Princeton, NJ: Princeton University Press.

Brandl, K., Darendeli, I., \& Mudambi, R. 2019. Foreign actors and intellectual property protection regulations in developing countries. Journal of International Business Studies, 50(5): 826-846.

Brewer, M. B. 1979. In-group bias in the minimal intergroup situation: A cognitive-motivational analysis. Psychological Bulletin, 86(2): 307.

Brewer, M. B. 1996. Managing diversity: The role of social identities. In S. Jackson \& M. Ruderman (Eds.), Diversity in work teams (pp. 47-68). Washington, DC: American Psychological Association.

Brewer, M. B., von Hippel, W., \& Gooden, M. P. 1999. Diversity and organizational identity: The problem of entree after entry. In D. A. Prentice \& D. T. Miller (Eds.), Cultural divides: Understanding and overcoming group conflict (pp. 337-363). New York, NY: Russell Sage Foundation.

Briscoe, F., \& Joshi, A. 2017. Bringing the boss's politics in: Supervisor political ideology and the gender gap in earnings. Academy of Management Journal, 60(4): 1415-1441.

Brouthers, K. D. 2013. Institutional, cultural and transaction cost influences on entry mode choice and performance. Journal of International Business Studies, 44(1): 1-13.

Buckley, P. J., Clegg, J., \& Wang, C. 2007. Is the relationship between inward FDI and spillover effects linear? An empirical examination of the case of China. Journal of International Business Studies, 38(3): 447-459.

Budd, J. W., Konings, J., \& Slaughter, M. J. 2005. Wages and international rent sharing in multinational firms. The Review of Economics and Statistics, 87(1): 73-84. 
Budig, M. J., \& England, P. 2001. The wage penalty for motherhood. American Sociological Review, 66(2): 204-225.

Budig, M. J., \& Hodges, M. J. 2010. Differences in disadvantage: Variation in the motherhood penalty across white women's earnings distribution. American Sociological Review, 75(5): 705-728.

Campbell, J. T., Eden, L., \& Miller, S. R. 2012. Multinationals and corporate social responsibility in host countries: Does distance matter? Journal of International Business Studies, 43(1): 84-106.

Cantwell, J., Dunning, J. H., \& Lundan, S. M. 2010. An evolutionary approach to understanding international business activity: The co-evolution of MNEs and the institutional environment. Journal of International Business Studies, 41(4): 567-586.

Cardador, M. T. 2017. Promoted up but also out? The unintended consequences of increasing women's representation in managerial roles in engineering. Organization Science, 28(4): 597-617.

Caves, R. E. 1996. Multinational enterprise and economic analysis. Cambridge: Cambridge University Press.

Chacar, A. S., Newburry, W., \& Vissa, B. 2010. Bringing institutions into performance persistence research: Exploring the impact of product, financial, and labor market institutions. Journal of International Business Studies, 41(7): 1119-1140.

Chang, S. J., Chung, J., \& Moon, J. J. 2013. When do wholly owned subsidiaries perform better than joint ventures? Strategic Management Journal, 34(3): 317-337.

Chen, C. C., Chen, X. P., \& Huang, S. 2013. Chinese Guanxi: An integrative review and new directions for future research. Management and Organization Review, 9(1): 167-207.

Chen, Z., Ge, Y., \& Lai, H. 2011. Foreign direct investment and wage inequality: Evidence from China. World Development, 39(8): 1322-1332.

Chen, T. Y., Zhang, G., \& Zhou, Y. 2018. Enforceability of noncompete covenants, discretionary investments, and financial reporting practices: Evidence from a natural experiment. Journal of Accounting and Economics, 65(1): 41-60.

Chung, C. C., Park, H. Y., Lee, J. Y., \& Kim, K. 2015. Human capital in multinational enterprises: Does strategic alignment matter? Journal of International Business Studies, 46(7): 806-829.

Clougherty, J. A., Gugler, K., Sørgard, L., \& Szücs, F. W. 2014. Cross-border mergers and domestic-firm wages: Integrating 'spillover effects' and 'bargaining effects'. Journal of International Business Studies, 45(4): 450-470.

Collings, D. G., Mellahi, K., \& Cascio, W. F. 2019. Global talent management and performance in multinational enterprises: A multilevel perspective. Journal of Management, 45(2): 540-566.

Conyon, M. J., Fernandes, N., Ferreira, M. A., Matos, P., \& Murphy, K. J. 2011. The executive compensation controversy: $A$ transatlantic analysis. New York: Cornell University.

Criscuolo, P., \& Narula, R. 2008. A novel approach to national technological accumulation and absorptive capacity: Aggregating Cohen and Levinthal. The European Journal of Development Research, 20(1): 56-73.

Da Silva Lopes, T., Casson, M., \& Jones, G. 2019. Organizational innovation in the multinational enterprise: Internalization theory and business history. Journal of International Business Studies, 50(8): 1338-1358.

Dau, L. A. 2018. Contextualizing international learning: The moderating effects of mode of entry and subsidiary networks on the relationship between reforms and profitability. Journal of World Business, 53(3): 403-414.

De Vries, D. H., Steinmetz, S., \& Tijdens, K. G. 2016. Does migration 'pay off' for foreign-born migrant health workers? An exploratory analysis using the global Wagelndicator dataset. Human Resources for Health, 14(1): 40-54

Demirbag, M., Ng, C. K., \& Tatoglu, E. 2007. Performance of mergers and acquisitions in the pharmaceutical industry: A comparative perspective. Multinational Business Review, 15(2): $41-62$.

Dikova, D., Sahib, P. R., \& Van Witteloostuijn, A. 2010. Crossborder acquisition abandonment and completion: The effect of institutional differences and organizational learning in the international business service industry, 1981-2001. Journal of International Business Studies, 41(2): 223-245.

Doh, J. P. 2019. MNEs, FDI, inequality and growth. Multinational Business Review, 27(3): 217-220.

Dow, D., Cuypers, I. R., \& Ertug, G. 2016. The effects of withincountry linguistic and religious diversity on foreign acquisitions. Journal of International Business Studies, 47(3): 319-346.

Driffield, N., Munday, M., \& Roberts, A. 2002. Foreign direct investment, transactions linkages, and the performance of the domestic sector. International journal of the Economics of Business, 9(3): 335-351.

Dunning, J. H. 1958. American investment in British manufacturing industry. London: George Allen and Unwin.

Dunning, J. H. 1981. Explaining the international direct investment position of countries: Towards a dynamic or developmental approach. Weltwirtschaftliches Archiv, 117(1): 30-64.

Dunning, J. H. 1988. The eclectic paradigm of international production: A restatement and some possible extensions. Journal of International Business Studies, 19(1): 1-31.

Dunning, J. H. 1994. Re-evaluating the benefits of foreign direct investment. Transnational Corporations, 3(1): 23-51.

Eden, L., \& Lenway, S. 2001. Introduction to the symposium multinationals: The Janus face of globalization. Journal of International Business Studies, 32(3): 383-400.

Edwards, T., \& Kuruvilla, S. 2005. International HRM: National business systems, organizational politics and the international division of labour in MNCs. International Journal of Human Resource Management, 16(1): 1-21.

Egels-Zandén, N. 2014. Revisiting supplier compliance with MNC codes of conduct: Recoupling policy and practice at Chinese toy suppliers. Journal of Business Ethics, 119(1): 59-75.

Egger, H., \& Kreickemeier, U. 2013. Why foreign ownership may be good for you. International Economic Review, 54(2): 693-716.

Einwiller, S., Ruppel, C., \& Schnauber, A. 2016. Harmonization and differences in CSR reporting of US and German companies: Analyzing the role of global reporting standards and country-of-origin. Corporate Communications: An International Journal, 21(2): 230-245.

Elvira, M. M., \& Graham, M. E. 2002. Not just a formality: Pay system formalization and sex-related earnings effects. Organization Science, 13(6): 601-617.

England, P. 2017. Comparable worth: Theories and evidence. New York: Routledge.

Farndale, E., Brewster, C., Ligthart, P., \& Poutsma, E. 2017. The effects of market economy type and foreign MNE subsidiaries on the convergence and divergence of HRM. Journal of International Business Studies, 48(9): 1065-1086.

Ferner, A., Quintanilla, I., \& Varul, M. Z. 2001. Country-of-origin effects, host-country effects, and the management of HR in multinationals: German companies in Britain and Spain. lournal of World Business, 36(2): 107-127.

Festing, M. 2012. Strategic human resource management in Germany: Evidence of convergence to the US model, the European model, or a distinctive national model? Academy of Management Perspectives, 26(2): 37-54.

Festing, M., Knappert, L., \& Kornau, A. 2015. Gender-specific preferences in global performance management: An empirical study of male and female managers in a multinational context. Human Resource Management, 54(1): 55-79.

Figueiredo, P. N. 2011. The role of dual embeddedness in the innovative performance of MNE subsidiaries: Evidence from Brazil. Journal of Management Studies, 48(2): 417-440.

Filatotchev, I., Strange, R., Piesse, J., \& Lien, Y. C. 2007. FDI by firms from newly industrialised economies in emerging markets: Corporate governance, entry mode and location. Journal of International Business Studies, 38(4): 556-572.

Fortanier, F. 2008. Multinational enterprises, institutions and sustainable development. Amsterdam: Unpublished PhD Dissertation, Amsterdam Business School, University of Amsterdam. 
Fortanier, F., \& Kolk, A. 2007. On the economic dimensions of corporate social responsibility: Exploring Fortune Global 250 reports. Business and Society, 46(4): 457-478.

Fortanier, F., Kolk, A., \& Pinkse, J. 2011. MNEs and global CSR standards: Harmonization in CSR reporting. Management International Review, 51(5): 665-697.

Fortanier, F., \& Van Wijk, J. 2010. Sustainable tourism industry development in sub-Saharan Africa: Consequences of foreign hotels for local employment. International Business Review, 19(2): 191-205.

Fosfuri, A., Motta, M., \& Rønde, T. 2001. Foreign direct investment and spillovers through workers' mobility. Journal of International Economics, 53(1): 205-222.

Frank, R., Akresh, I. R., \& Lu, B. 2010. Latino immigrants and the US racial order: How and where do they fit in? American Sociological Review, 75(3): 378-401.

Fuller, S., \& Cooke, L. P. 2018. Workplace variation in fatherhood wage premiums: Do formalization and performance pay matter? Work, Employment \& Society, 32(4): 768-788.

Garrido, E., Gomez, J., Maicas, J. P., \& Orcos, R. 2014. The institution-based view of strategy: How to measure it. $B R Q$ Business Research Quarterly, 17(2): 82-101.

Ghauri, P. N., \& Yamin, M. 2009. Revisiting the impact of multinational enterprises on economic development. Journal of World Business, 44(2): 105-107.

Girma, S., Görg, H., \& Kersting, E. 2019. Which boats are lifted by a foreign tide? Direct and indirect wage effects of foreign ownership. Journal of International Business Studies, 50(6): 923-947.

Giroud, A. 2007. MNEs vertical linkages: The experience of Vietnam after Malaysia. International Business Review, 16(2): 159-176.

Giuliani, E. 2019. Why multinational enterprises may be causing more inequality than we think. Multinational Business Review, 27(3): 221-225

Giuliani, E., \& Macchi, C. 2014. Multinational corporations' economic and human rights impacts on developing countries: A review and research agenda. Cambridge Journal of Economics, 38: 479-517.

Glass, A. J., \& Saggi, K. 1999. FDI policies under shared factor markets. lournal of International Economics, 49(2): 309-332.

Glass, A. J., \& Saggi, K. 2002. Multinational firms and technology transfer. The Scandinavian Journal of Economics, 104(4): 495-513.

Globerman, S., Ries, J. C., \& Vertinsky, I. 1994. The economic performance of foreign affiliates in Canada. Canadian Journal of Economics, 27(1): 143-156.

Görg, H., Strobl, E., \& Walsh, F. 2007. Why do foreign-owned firms pay more? The role of on-the-job training. Review of World Economics, 143(3): 464-482.

Greenaway, D., \& Kneller, R. 2007. Firm heterogeneity, exporting and foreign direct investment. The Economic Journal, 117(517): 134-161.

Gubbi, S. R., Aulakh, P. S., Ray, S., Sarkar, M. B., \& Chittoor, R. 2010. Do international acquisitions by emerging-economy firms create shareholder value? The case of Indian firms. Journal of International Business Studies, 41(3): 397-418.

Guthridge, M., \& Komm, A. B. 2008. Why multinationals struggle to manage talent. The McKinsey Quarterly, 4, 10-13.

Ha, Y. J., \& Giroud, A. 2015. Competence-creating subsidiaries and FDI technology spillovers. International Business Review, 24(4): 605-614.

Hair, J. F., Anderson, R., Tatham, R. L., \& Black, W. C. 1998. Multivariate data analysis. Upper Saddle River: Prentice Hall.

Hall, R. E. 2005. Employment efficiency and sticky wages: Evidence from flows in the labor market. The Review of Economics and Statistics, 87(3): 397-407.

Harrison, D. A., Harrison, T., \& Shaffer, M. A. 2019. Strangers in strained lands: Learning from workplace experiences of immigrant employees. Journal of Management, 45(2): 600-619.

Harzing, A. W. 2001. Of bears, bumble-bees, and spiders: The role of expatriates in controlling foreign subsidiaries. Journal of World Business, 36(4): 366-379.
Haskell, J., Lawrence, R. Z., Leamer, E. E., \& Slaughter, M. J. 2012. Globalization and US wages: Modifying classic theory to explain recent facts. Journal of Economic Perspectives, 26(2): 119-140.

Haslam, S. A., \& Ellemers, N. 2005. Social identity in industrial and organizational psychology: Concepts, controversies and contributions. International Review of Industrial and Organizational Psychology, 20(1): 39-118.

Heckman, J. J. 1979. Sample selection bias as a specification error. Econometrica, 47(1): 153-161.

Helpman, E., Itskhoki, O., \& Redding, S. 2010. Inequality and unemployment in a global economy. Econometrica, 78(4): 1239-1283.

Hermans, M., Newburry, W., Alvarado-Vargas, M. J., Baldo, C. M., Borda, A., Durán-Zurita, E. G., et al. 2017. Attitudes towards women's career advancement in Latin America: The moderating impact of perceived company international proactiveness. Journal of International Business Studies, 48(1): 90-112.

Hewlett, S. A., \& Rashid, R. 2010. The battle for female talent in emerging markets. Harvard Business Review, 88(5): 101-106.

Heyman, F., Sjöholm, F., \& Tingvall, P. G. 2007. Is there really a foreign ownership wage premium? Evidence from matched employer-employee data. Journal of International Economics, 73(2): 355-376.

Hijzen, A., Martins, P. S., Schank, T., \& Upward, R. 2013. Foreign-owned firms around the world: A comparative analysis of wages and employment at the micro-level. European Economic Review, 60(C): 170-188.

Hofstede, G. 1980. Culture's consequences: International differences in work-related values. Beverly Hills: Sage.

Hogg, M. A., \& Terry, D. I. 2000. Social identity and selfcategorization processes in organizational contexts. Academy of Management Review, 25(1): 121-140.

Hon, A. H. Y., \& Lu, L. 2015. Are we paid to be creative? The effect of compensation gap on creativity in an expatriate context. Journal of World Business, 50(1): 159-167.

House, R. J., Hanges, P. J., Javidan, M., Dorfman, P. W., \& Gupta, V. (Eds.) 2004. Culture, leadership, and organizations: The GLOBE study of 62 societies. Thousand Oaks: Sage Publications.

Hox, J. 2010. Multilevel analysis. Techniques and applications. New York: Routledge.

Hymer, S. 1975. The multinational corporation and the law of uneven development. In H. Radice (Ed.), International firms and modern imperialism (pp. 45-67). Handsworth: Penguin.

ILO. 2011. Earnings and labour cost. Geneva: International Labour Organization.

ILO. 2018. Global wage report 2018/2019: What lies behind gender pay gaps. Geneva: International Labour Organization.

Jandhyala, S. 2013. Property rights and international investment in information technology services. Strategic Management Journal, 34(7): 877-889.

Javorcik, B. 2004. Does foreign direct investment increase the productivity of domestic firms? In search of spillovers through backward linkages. American Economic Review, 94(3): 605-627.

Javorcik, B. 2014. Does FDI bring good jobs to host countries? The World Bank Research Observer, 30(1): 74-94.

Javorcik, B., \& Poelhekke, S. 2017. Former foreign affiliates: Cast out and outperformed? Journal of the European Economic Association, 15(3): 501-539.

jiang, C. X., Chua, R. Y., Kotabe, M., \& Murray, J. Y. 2011. Effects of cultural ethnicity, firm size, and firm age on senior executives' trust in their overseas business partners: Evidence from China. Journal of International Business Studies, 42(9): 1150-1173.

Jindra, B., Giroud, A., \& Scott-Kennel, J. 2009. Subsidiary roles, vertical linkages and economic development: Lessons from transition economies. Journal of World Business, 44(2): 167-179. 
Johanson, J., \& Vahlne, J.-E. 2009. The Uppsala internationalization process model revisited: From liability of foreignness to liability of outsidership. Journal of International Business Studies, 40(9): 1411-1431.

Kalasin, K., Dussauge, P., \& Rivera-Santos, M. 2014. The expansion of emerging economy firms into advanced markets: The influence of intentional path-breaking change. Global Strategy Journal, 4(2): 75-103.

Katz, L. F., \& Revenga, A. L. 1989. Changes in the structure of wages: The United States vs Japan. Journal of the Japanese and International Economies, 3(4): 522-553.

Killewald, A., \& García-Manglano, J. 2016. Tethered lives: A couple-based perspective on the consequences of parenthood for time use, occupation, and wages. Social Science Research, 60: 266-282.

Kim, K. Y., Pathak, S., \& Werner, S. 2015. When do international human capital enhancing practices benefit the bottom line? An ability, motivation, and opportunity perspective. Journal of International Business Studies, 46(7): 784-805.

Kirkman, B. L., Lowe, K. B., \& Gibson, C. B. 2017. A retrospective on Culture's Consequences: The 35-year journey. Journal of International Business Studies, 48(1): 12-29.

Kobrin, S. J. 2017. Bricks and mortar in a borderless world: Globalization, the backlash, and the Multinational Enterprise. Global Strategy Journal, 7(2): 159-171.

Kolk, A. 2010. Social and sustainability dimensions of regionalization and (semi) globalization. Multinational Business Review, 18(1): 51-72.

Kolk, A. 2016. The social responsibility of international business: From ethics and the environment to CSR and sustainable development. Journal of World Business, 51(1): 23-34.

Kolk, A., \& Fortanier, F. 2013. Internationalization and environmental disclosure: The role of home and host institutions. Multinational Business Review, 21(1): 87-114.

Kolk, A., \& Lenfant, F. 2015. Cross-sector collaboration, institutional gaps and fragility: The role of social innovation partnerships in a conflict-affected region. Journal of Public Policy \& Marketing, 34(2): 287-303.

Kolk, A., \& Lenfant, F. 2018. Responsible business under adverse conditions: Dilemmas regarding company contributions to local development. Business Strategy and Development, 1(1): 8-16.

Kostova, T., \& Roth, K. 2002. Adoption of an organizational practice by subsidiaries of multinational corporations: Institutional and relational effects. Academy of Management Journal, 45(1): 215-233.

Kostova, T., Roth, K., \& Dacin, M. T. 2008. Institutional theory in the study of multinational corporations: A critique and new directions. Academy of Management Review, 33(4): 994-1006.

Kostova, T., \& Zaheer, S. 1999. Organizational legitimacy under conditions of complexity: The case of the multinational enterprise. Academy of Management Review, 24(1): 64-81.

Kourula, A., \& Laasonen, S. 2010. Nongovernmental organizations in business and society, management, and international business research: Review and implications from 1998 to 2007. Business and Society, 49(1): 35-67.

Kwok, C. C., \& Tadesse, S. 2006. The MNC as an agent of change for host-country institutions: FDI and corruption. Journal of International Business Studies, 37(6): 767-785.

Lall, S. 1980. The multinational corporation. London: Palgrave Macmillan.

Lall, S., \& Narula, R. 2004. Foreign direct investment and its role in economic development: Do we need a new agenda? The European Journal of Development Research, 16(3): 447-464.

Le, S., \& Kroll, M. 2017. CEO international experience: Effects on strategic change and firm performance. Journal of International Business Studies, 48(5): 573-595.

Lee, J. W., \& Wie, D. 2015. Technological change, skill demand, and wage inequality: Evidence from Indonesia. World Development, 67: 238-250.
$\mathrm{Li}, \mathrm{X} .2008$. The impact of higher standards in patent protection for pharmaceutical industries under the TRIPS agreement: A comparative study of China and India. World Economy, 31(10): 1367-1382.

Li, J. T., \& Qian, C. 2013. Principal-principal conflicts under weak institutions: A study of corporate takeovers in China. Strategic Management Journal, 34(4): 498-508.

Li, S., \& Scullion, H. 2010. Developing the local competence of expatriate managers for emerging markets: A knowledgebased approach. Journal of World Business, 45(2): 190-196.

Lipsey, R. E., \& Sjöholm, F. 2004. Foreign direct investment, education and wages in Indonesian manufacturing. Journal of Development Economics, 73(1): 415-422.

Luo, Y., Zhang, H., \& Bu, J. 2019. Developed country MNEs investing in developing economies: Progress and prospect. Journal of International Business Studies, 50(4): 633-667.

Maggioni, D., Santangelo, G. D., \& Koymen-Ozer, S. 2019. MNEs' location strategies and labor standards: The role of operating and reputational considerations across industries. Journal of International Business Studies, 50(6): 948-972.

Mäkelä, K., Björkman, I., \& Ehrnrooth, M. 2010. How do MNCs establish their talent pools? Influences on individuals' likelihood of being labeled as talent. Journal of World Business, 45(2): 134-142.

Marano, V., Arregle, J. L., Hitt, M. A., Spadafora, E., \& Van Essen, M. 2016. Home country institutions and the internationalization-performance relationship: A meta-analytic review. Journal of Management, 42(5): 1075-1110.

Marano, V., Tashman, P., \& Kostova, T. 2017. Escaping the iron cage: Liabilities of origin and CSR reporting of emerging market multinational enterprises. Journal of International Business Studies, 48(3): 386-408.

Márquez-Ramos, L. 2018. Value-chain activities and individual wages. Critical Perspectives on International Business. https:// doi.org/10.1108/cpoib-12-2017-0102.

Martin, X., \& Salomon, R. 2003. Knowledge transfer capacity and its implications for the theory of the multinational corporation. Journal of International Business Studies, 34(4): 356-373.

Martins, P. S., \& Yang, Y. 2015. Globalized labour markets? International rent sharing across 47 countries. British Journal of Industrial Relations, 53(4): 664-691.

Mauri, A., Song, S., \& Neiva de Figueiredo, J. 2017. Determinants of corporate international expansion beyond the home region: An empirical examination of U.S. Multinational Enterprises expansion to Europe and Asia-Pacific. Global Strategy Journal, 7(4): 400-426.

McDonald, M. L., Keeves, G. D., \& Westphal, J. D. 2018. One step forward, one step back: White male top manager organizational identification and helping behavior toward other executives following the appointment of a female or racial minority CEO. Academy of Management Journal, 61(2): 405-439.

McDonnell, A., Lamare, R., Gunnigle, P., \& Lavelle, J. 2010. Developing tomorrow's leaders - Evidence of global talent management in multinational enterprises. Journal of World Business, 45(2): 150-160.

Mellahi, K., \& Collings, D. G. 2010. The barriers to effective global talent management: The example of corporate elites in MNEs. Journal of World Business, 45(2): 143-149.

Mellahi, K., Demirbag, M., Collings, D. G., Tatoglu, E., \& Hughes, M. 2013. Similarly different: A comparison of HRM practices in MNE subsidiaries and local firms in Turkey. The International Journal of Human Resource Management, 24(12): 2339-2368.

Meyer, K. E. 2004. Perspectives on multinational enterprises in emerging economies. Journal of International Business Studies, 35(4): 259-276.

Meyer, K. E., Mudambi, R., \& Narula, R. 2011. Multinational enterprises and local contexts: The opportunities and challenges of multiple embeddedness. Journal of Management Studies, 48(2): 235-252. 
Meyer, K. E., \& Peng, M. W. 2005. Probing theoretically into Central and Eastern Europe: Transactions, resources, and institutions. Journal of International Business Studies, 36(6): 600-621.

Meyer, K. E., \& Peng, M. W. 2016. Theoretical foundations of emerging economy business research. Journal of International Business Studies, 47(1): 3-22.

Meyer, K. E., \& Sinani, E. 2009. When and where does foreign direct investment generate positive spillovers? A meta-analysis. Journal of International Business Studies, 40(7): 1075-1094.

Meyer, K. E., Van Witteloostuijn, A., \& Beugelsdijk, S. 2017. What's in a p? Reassessing best practices for conducting and reporting hypothesis-testing research. Journal of International Business Studies, 48(5): 535-551.

Meyer, K. E., \& Xin, K. R. 2018. Managing talent in emerging economy multinationals: Integrating strategic management and human resource management. The International Journal of Human Resource Management, 29(11): 1827-1855.

Milanovic, B. 2016. Global inequality: A new approach for the age of globalization. Cambridge, MA: Harvard University Press.

Miller, T., Holmes, K. R., \& Feulner, E. J. 2013. 2013 Index of economic freedom. Washington, DC: The Heritage Foundation.

Miller, T., Kim, A., \& Roberts, J. 2019. 2019 Index of economic freedom. Washington, D.C.: The Heritage Foundation.

Miozzo, M., \& Grimshaw, D. 2008. Service multinationals and forward linkages with client firms: The case of IT outsourcing in Argentina and Brazil. International Business Review, 17(1): 8-27.

Morris, S., Snell, S., \& Björkman, I. 2016. An architectural framework for global talent management. Journal of International Business Studies, 47(6): 723-747.

Mueller, H. M., Ouimet, P. P., \& Simintzi, E. 2017. Wage inequality and firm growth. American Economic Review, 107(5): 379-383.

Narula, R. 2014. Foreign direct investment as a driver of industrial development: Why is there so little evidence? In R. Van Tulder, A. Verbeke, \& R. Strange (Eds.), International business and sustainable development (pp. 45-67). Bingley: Emerald Group Publishing Limited.

Narula, R. 2018. Multinational firms and the extractive sectors in the 21st century: Can they drive development? Journal of World Business, 53(1): 85-91.

Narula, R. 2019. Enforcing higher labor standards within developing country value chains: Consequences for MNEs and informal actors in a dual economy. Journal of International Business Studies, 50(9): 1622-1635.

Narula, R., Asmussen, C. G., Chi, T., \& Kundu, S. K. 2019. Applying and advancing internalization theory: The multinational enterprise in the twenty-first century. Journal of International Business Studies, 50(8): 1231-1252.

Narula, R., \& Driffield, N. 2012. Does FDI cause development? The ambiguity of the evidence and why it matters. The European Journal of Development Research, 24(1): 1-7.

Narula, R., \& Dunning, J. H. 2010. Multinational enterprises, development and globalization: Some clarifications and a research agenda. Oxford Development Studies, 38(3): 263-287.

Narula, R., \& Verbeke, A. 2015. Making internalization theory good for practice: The essence of Alan Rugman's contributions to international business. Journal of World Business, 50(4): 612-622.

Nolan, N., Salverda, W., Checchi, D., Marx, I., McKnight, A., György Tóth, I., et al. (Eds.). 2014. Changing inequalities and societal impacts in rich countries: Thirty countries' experiences. Oxford: Oxford University Press.

Oetzel, J., \& Doh, J. P. 2009. MNEs and development: A review and reconceptualization. Journal of World Business, 44(2): $108-120$.

Ollo-Lopez, A., Bayo-Moriones, A., \& Larraza-Kintana, M. 2011. The impact of country-level factors on the use of new work practices. Journal of World Business, 46(3): 394-403.

Parmigiani, A., \& Rivera-Santos, M. 2015. Sourcing for the base of the pyramid: Constructing supply chains to address voids in subsistence markets. Journal of Operations Management, 33: 60-70.

Pavcnik, N., Blom, A., Goldberg, P., \& Schady, N. 2004. Trade liberalization and industry wage structure: Evidence from Brazil. The World Bank Economic Review, 18(3): 319-344.

Peng, M. W., Wang, D. Y., \& Jiang, Y. 2008. An institution-based view of international business strategy: A focus on emerging economies. Journal of International Business Studies, 39(5): 920-936.

Peterson, M. F., Arregle, J. L., \& Martin, X. 2012. Multilevel models in international business research. Journal of International Business Studies, 43(5): 451-457.

Pinkse, J., \& Kolk, A. 2012. Multinational enterprises and climate change: Exploring institutional failures and embeddedness. Journal of International Business Studies, 43(3): 332-341.

Pisani, N., Kourula, A., Kolk, A., \& Meijer, R. 2017. How global is international CSR research? Insights and recommendations from a systematic review. Journal of World Business, 52(5): 591-614.

Pisani, N., \& Ricart, J. E. 2018. Offshoring innovation to emerging countries: The effects of IP protection and cultural differences on firms' decision to augment versus exploit home-base-knowledge. Management International Review, 58(6): 871-909.

Podsakoff, P. M., MacKenzie, S. B., Lee, J. Y., \& Podsakoff, N. P. 2003. Common method biases in behavioral research: $A$ critical review of the literature and recommended remedies. Journal of Applied Psychology, 88(5): 879-903.

Pudelko, M., \& Harzing, A. W. 2007. Country-of-origin, localization, or dominance effect? An empirical investigation of HRM practices in foreign subsidiaries. Human Resource Management, 46(4): 535-559.

Rabe-Hesketh, S., \& Skrondal, A. 2008. Multilevel and longitudinal modeling using Stata. College Station: STATA Press.

Ready, D. A., Hill, L. A., \& Conger, J. A. 2008. Winning the race for talent in emerging markets. Harvard Business Review, 86(11): 62-70.

Regnér, P., \& Edman, J. 2014. MNE institutional advantage: How subunits shape, transpose and evade host country institutions. Journal of International Business Studies, 45(3): 275-302.

Reiche, B. S., Harzing, A. W., \& Pudelko, M. 2015. Why and how does shared language affect subsidiary knowledge inflows? A social identity perspective. Journal of International Business Studies, 46(5): 528-551.

Rickley, M. 2019. Cultural generalists and cultural specialists: Examining international experience portfolios of subsidiary executives in multinational firms. Journal of Management, 45(2): 384-416.

Rodrik, D. 2018. Populism and the economics of globalization. Journal of International Business Policy, 1(1): 12-33.

Rosenzweig, P. 1998. Managing the new global workforce: Fostering diversity, forging consistency. European Management Journal, 16(6): 644-652.

Rugman, A. M., \& Verbeke, A. 2001. Subsidiary-specific advantages in multinational enterprises. Strategic Management Journal, 22(3): 237-250.

Rugman, A., \& Verbeke, A. 2003. Extending the theory of the multinational enterprise: Internalization and strategic management perspectives. Journal of International Business Studies, 34(1): 125-137.

Ruigrok, W., \& Wagner, H. 2003. Internationalization and performance: An organizational learning perspective. Management International Review, 43(1): 63-84.

Samuelson, P., \& Scotchmer, S. 2002. The law and economics of reverse engineering. The Yale Law Journal, 111(7): 1575-1663.

Santangelo, G. D. 2018. The impact of FDI in land in agriculture in developing countries on host country food security. Journal of World Business, 53(1): 75-84.

Sarabi, A., Froese, F. J., \& Hamori, M. 2017. Is inpatriate assignment experience a ticket to the top of a foreign 
subsidiary? The moderating effect of subsidiary context. Journal of World Business, 52(5): 680-690.

Schuler, R. S., \& Rogovsky, N. 1998. Understanding compensation practice variations across firms: The impact of national culture. Journal of International Business Studies, 29(10): 159-177.

Sinani, E., \& Meyer, K. E. 2004. Spillovers of technology transfer from FDI: The case of Estonia. Journal of Comparative Economics, 32(3): 445-466.

Smith, P. B., Torres, C., Leong, C. H., Budhwar, P., Achoui, M., $\&$ Lebedeva, N. 2012. Are indigenous approaches to achieving influence in business organizations distinctive? A comparative study of guanxi, wasta, jeitinho, svyazi and pulling strings. The International Journal of Human Resource Management, 23(2): 333-348.

Southam, C., \& Sapp, S. 2010. Compensation across executive labor markets: what can we learn from cross-listed firms? Journal of International Business Studies, 41(1): 70-87.

Strange, R., \& Humphrey, J. 2019. What lies between market and hierarchy? Insights from internalization theory and global value chain theory. Journal of International Business Studies, 50(8): 1401-1413.

Sugathan, A., \& George, R. 2015. The influence of governance infrastructure and corporate governance on profit sharing. Journal of International Business Studies, 46(8): 886-916.

Tajfel, H. (Ed.). 1978. Differentiation between social groups: Studies in the social psychology of intergroup relations. London: Academic Press.

Tajfel, H. 1982. Social psychology of intergroup relations. Annual Review of Psychology, 33(1): 1-39.

Tajfel, H., \& Turner, J. C. 1986. The social identity theory of intergroup behavior. In S. Worchel \& W. G. Austin (Eds.), Psychology of intergroup relations (pp. 7-24). Chicago, IL: Nelson-Hall.

Tarique, I., Schuler, R., \& Gong, Y. 2006. A model of multinational enterprise subsidiary staffing composition. International Journal of Human Resource Management, 17(2): 207-224.

Tatoglu, E., Glaister, A. J., \& Demirbag, M. 2016. Talent management motives and practices in an emerging market: A comparison between MNEs and local firms. Journal of World Business, 51(2): 278-293.

Taylor, S., Beechler, S., \& Napier, N. 1996. Toward an integrative model of strategic international human resource management. Academy of Management Review, 21(4): 959-985.

Testa, F., Boiral, O., \& Iraldo, F. 2018. Internalization of environmental practices and institutional complexity: Can stakeholders pressures encourage greenwashing? Journal of Business Ethics, 147(2): 287-307.

The Economist. 2018. Immigrants and the wage gap. https:// www.economist.com/democracy-in-america/2018/07/30/ immigrants-and-the-wage-gap.

Tijdens, K., Beblavý, M., \& Thum-Thysen, A. 2018. Skill mismatch comparing educational requirements vs attain- ments by occupation. International Journal of Manpower, 39(8): 996-1009.

Tijdens, K., \& Osse, P. 2018. Wagelndicator continuous websurvey on work and wages. Dataset 2013-2014. Amsterdam: Wagelndicator Foundation.

Tijdens, K., Van Zijl, S., Hughie-Williams, M., Van Klaveren, M., \& Steinmetz, S. 2010. Codebook and explanatory note on the Wagelndicator dataset: a worldwide, continuous, multilingual web-survey on work and wages with paper supplements. Amsterdam: Amsterdam Institute for Advanced Labour Studies.

Trompenaars, F. 1993. Riding the waves of culture: Understanding cultural diversity in business. London: The Economist Books.

Tsui, A. S., \& O'Reilly, C. A., III. 1989. Beyond simple demographic effects: The importance of relational demography in superior-subordinate dyads. Academy of Management Journal, 32(2): 402-423.

Turner, I. C. 1982. Towards a cognitive redefinition of the social group. In $\mathrm{H}$. Tajfel (Ed.), Social identity and intergroup relations (pp. 15-40). New York, NY: Cambridge University Press.

Van de Vliert, E. 2003. Thermoclimate, culture, and poverty as country-level roots of workers' wages. Journal of International Business Studies, 34(1): 40-52.

Van Essen, M., Heugens, P. P., Otten, J., \& Van Oosterhout, J. H. 2012. An institution-based view of executive compensation: A multilevel meta-analytic test. Journal of International Business Studies, 43(4): 396-423.

Verbeke, A. 2009. International business strategy. Cambridge: Cambridge University Press.

Vora, D., Martin, L., Fitzsimmons, S. R., Pekerti, A. A., Lakshman, C., \& Raheem, S. 2019. Multiculturalism within individuals: A review, critique, and agenda for future research. Journal of International Business Studies, 50(4): 499-524.

Wilkinson, R. G., \& Pickett, K. 2009. The spirit level: Why more equal societies almost always do better. New York: Bloomsbury Publishing.

Young, S. L., Welter, C., \& Conger, M. 2018. Stability vs. flexibility: The effect of regulatory institutions on opportunity type. Journal of International Business Studies, 49(4): 407-441.

Zanfei, A. 2012. Effects, not externalities. The European Journal of Development Research, 24(1): 8-14.

Zhao, M. 2006. Conducting R\&D in countries with weak intellectual property rights protection. Management Science, 52(8): 1185-1199.

Zikic, J., Bonache, J., \& Cerdin, J. L. 2010. Crossing national boundaries: A typology of qualified immigrants' career orientations. Journal of Organizational Behavior, 31(5): 667-686.

Ziliak, S. T., \& McCloskey, D. N. 2004. Size matters: the standard error of regressions in the American Economic Review. The Journal of Socio-Economics, 33(5): 527-546.

\section{APPENDIX: INFORMATION ON THE WAGEINDICATOR DATASET}

The WageIndicator project ${ }^{7}$ was initiated in 1999 in the Netherlands. It launched its first WageIndicator survey in 2001 through a large-scale, paper-based survey in the three largest Dutch women's magazines, aiming to shed light on the gender wage gap. Since then, the goal of the project has expanded to improving the overall transparency of labor mar- kets worldwide. To do so, a continuous on- and offline survey has been launched in 92 countries by now. The survey and data are owned by the WageIndicator Foundation. This foundation is a non-profit coalition of researchers (mainly from AIAS, the University of Amsterdam Institute for Labour Studies), trade unions, and web journalists. The anonymous WageIndicator survey includes 
questions on the employer, job content, employment history, working conditions, contract terms, wage, and personal characteristics of individual employees. By cooperating with local labor unions, the WageIndicator survey has managed to attract large numbers of web visitors (32 million in 2015) and completed surveys. In addition to the online survey filled out by web visitors, an offline version is available in countries with low literacy rates, which are completed with the help of an interviewer. Previous research has found the WageIndicator dataset to be representative in terms of the distribution across industries (Fortanier, 2008) and employees' demographics, even though employees with a low level of literacy (i.e., with a low level of education, corresponding to a value of 0 for the Education variable in our sample) as well as employees over the age of 50 were found to be relatively underrepresented in the dataset (De Vries, Tijdens, \& Steinmetz, 2016; Tijdens, Beblavý, \& Thum-Thysen, 2018). While this is a limitation, it does not undermine the value of our study given that (a) key groupings in terms of both education and age levels are well represented in the dataset and thus in our sample; (b) we account for different levels of education and age/experience in our estimations; and (c) we are interested in the comparison of MNEs versus domestic firms' employees having similar education levels and age/experience.

We also assessed the overall distribution of employees across the 13 countries considered in our sample as well as the representativeness of our sample relative to each of these countries' labor force. This is because, in view of the large variety and number of countries included in the WageIndicator survey, we expect that for some countries the WageIndicator is likely to represent a relatively more reliable source of information regarding wages than for others. Table 1 shows that all countries included in our sample of over 40,000 employees are represented with a relevant number of employees (ranging from 5\% of Czech and Mexican employees to $17 \%$ of German ones). We then calculated the ratio of each country's employees included in our sample as a share of the total labor force of the corresponding country (using data from the World Bank). As shown in Table 9 , as a result of the overall size of the labor force in some countries (especially Brazil and India), the ratio for such countries is lower while being higher for smaller countries such as Slovakia.

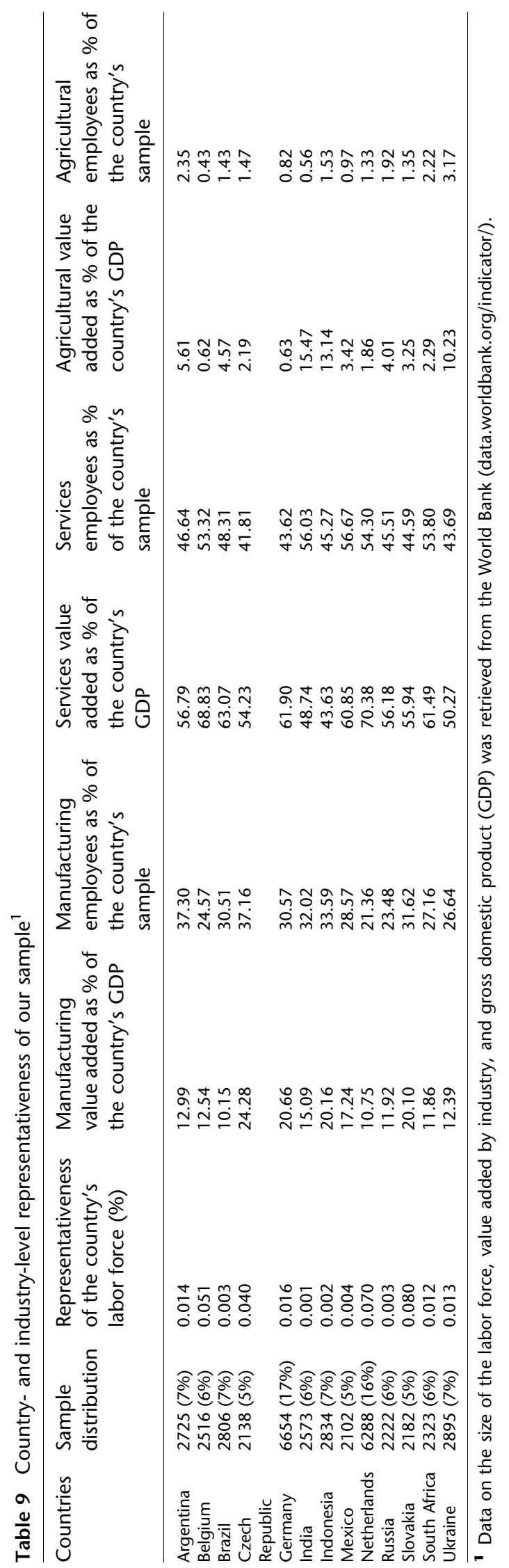


To better address the representativeness of the different sectors of each of the 13 countries' economies, we calculated the relative weight of the manufacturing, services, and agricultural sectors and compared it with the distribution of employees across these sectors in our sample. Table 9 shows a relative overrepresentation of the manufacturing sector and underrepresentation of the agricultural one (especially for India and Indonesia, this being related to the relative underrepresentation of employees with a low level of literacy in the WageIndicator dataset as discussed above). Having said that, the greater focus on the services and manufacturing sectors resonates well with our overall objective to examine wage differences between MNEs and domestic firms. While the relative underrepresentation of some sectors for some of the countries included in our sample as well as the relatively limited number of observations for some of them (especially for very large countries such as India, Russia, and Brazil) remain a limitation, the careful steps undertaken by the WageIndicator Foundation in the data gathering process make its dataset a reliable source of information on wages across country contexts. Still, to better account for differences across countries and industries in our estimation, as discussed in the methodology section of our work, we also included the country and industry level in our multilevel mixed effects model so as to control for unobserved country and industry characteristics (in the country- and industry-level intercepts) and for the effect that these characteristics may have on the relationship between MNE and Wage (in the country- and industry-level MNE slope).

Thus, while acknowledging the limitations of the WageIndicator dataset, we emphasize here that the clear benefit of using it for our work is that it provides detailed data on key variables needed to model and explore global patterns of wages in MNEs (versus domestic firms) across a variety of institutional settings. Whereas a number of national statistics offices and the ILO have statistics on earnings, including breakdowns by gender and industry, there is a considerable difference in the sources and methods used for earnings data collection and compilation between countries which makes comparability across countries imperfect (Hijzen et al., 2013; ILO, 2011). The WageIndicator dataset is therefore to date the most suitable source of cross-country data on wages that allows for an in-depth comparison of MNEs versus domestic firms across countries.

\section{ABOUT THE AUTHORS}

Khadija van der Straaten is a PhD Candidate at the University of Amsterdam, Amsterdam Business School and lecturer at the Rotterdam Business School, Rotterdam University of Applied Sciences, both in the Netherlands. Her research interests include sustainable development, inequality and gender issues.

Niccolò Pisani is Associate Professor of Strategy and International Business at the University of Amsterdam, Amsterdam Business School, The Netherlands. His areas of expertise are strategic management and international business. Among the topics of his scholarly enquiry are global strategy, international corporate social responsibility, and offshoring. His research has appeared in a variety of academic journals and practitioner-oriented outlets.

Ans Kolk is full professor at the University of Amsterdam, Amsterdam Business School, the Netherlands. Her areas of expertise are in corporate social responsibility, sustainable development and sustainability, especially in IB and related GVCs. She has published numerous articles in international reputable journals, as well as book chapters and books. For more information and an overview of publications, see http://www.anskolk. eu.

Publisher's Note Springer Nature remains neutral with regard to jurisdictional claims in published maps and institutional affiliations.

Accepted by Rajneesh Narula, Area Editor, 22 October 2019. This article has been with the authors for three revisions. 